[VOL. XXX, NO. 1 1992]

\title{
OVERVIEW OF THE INVESTMENT CANADA ACT WITH A FOCUS ON INVESTMENTS IN CANADA'S UPSTREAM OIL AND GAS INDUSTRY
}

\author{
M. JACQUELINE SHEPPARD AND \\ MUNGO HARDWICKE-BROWN*
}

Foreign investment has always played a significant role in Canada's petroleum industry. The authors trace the history of the regulation of foreign investment in general through its various phases: the early laissez-faire regime. followed by the Foreign Investment Review Act, followed in turn by the present Investment Canada Act. They then presem a detailed review of the present regime as it applies to oil and gas acquisitions. with examples of recent cases.

\section{TABLE OF CONTENTS}

I. INTRODUCTION AND SCOPE OF ANALYSIS $\ldots \ldots \ldots \ldots \ldots 5$

II. PAST CANADIAN FOREIGN OWNERSHIP POLICY $\ldots \ldots \ldots \ldots$

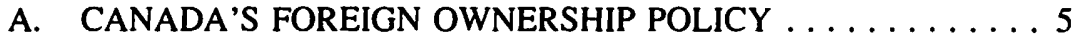

B. "KEY SECTOR" FOREIGN OWNERSHIP POLICY $\ldots \ldots \ldots 6$

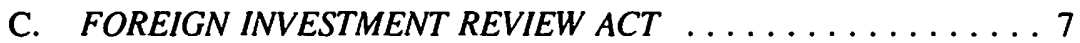

D. LIBERAL GOVERNMENT POLICY DURING

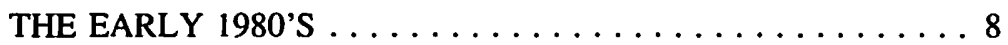

E. INTRODUCTION OF THE INVESTMENT

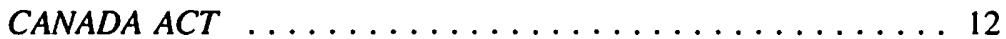

F. CONTINUING RESTRICTIONS IN THE
OIL AND GAS SECTOR $\ldots \ldots \ldots \ldots \ldots \ldots \ldots \ldots 14$

G. CONTRAST BETWEEN ICA AND FIRA $\ldots \ldots \ldots \ldots \ldots 15$

H. CONCLUSION .................... 15

III. OVERVIEW OF THE INVESTMENT

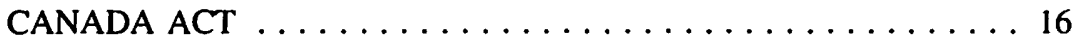

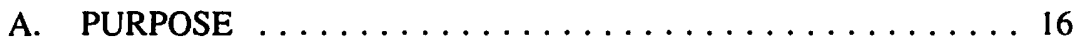

B. EXEMPT INVESTMENTS $\ldots \ldots \ldots \ldots \ldots \ldots \ldots \ldots$

C. NOTIFIABLE INVESTMENTS $\ldots \ldots \ldots \ldots \ldots \ldots \ldots 17$

D. REVIEWABLE TRANSACTIONS $\ldots \ldots \ldots \ldots \ldots \ldots \ldots$

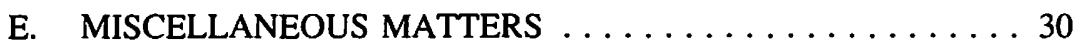

IV. STRUCTURING UPSTREAM INVESTMENTS $\ldots \ldots \ldots \ldots \ldots 32$

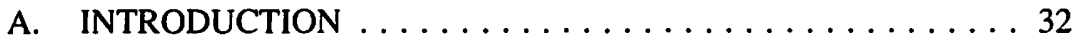

B. NATIONAL POLICY RESPECTING ACQUISITION OF OIL AND GAS BUSINESSES $\ldots \ldots \ldots \ldots \ldots \ldots \ldots$

C. FOCUS ON OIL AND GAS

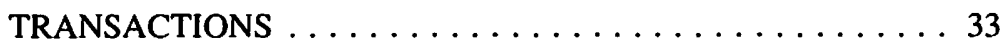

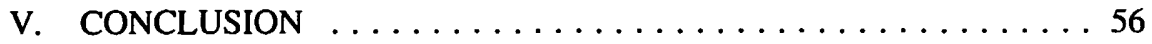

The authors are members of Blake, Cassels \& Graydon, Calgary, Alberta. 


\section{INTRODUCTION AND SCOPE OF ANALYSIS}

This paper reviews the Investment Canada Act' (the ICA or the Act) and Canada's current policy on foreign investment in the upstream petroleum and natural gas industry. The paper consists of three parts: an historical overview tracing the Canadianization policy in the upstream; a review of the structure and scheme of the ICA; and a detailed analysis of methods of completing acquisitions that have passed the scrutiny of the review agency.

The general thesis of the paper is that notwithstanding Canada's long standing Canadianization objectives, the Act is currently being administrated in a manner which is supportive and conducive to upstream investments.

\section{PAST CANADIAN FOREIGN OWNERSHIP POLICY}

\section{A. CANADA'S FOREIGN OWNERSHIP POLICY}

Canada's foreign ownership policy is very long rooted. External capital has always played an important role in Canada's history and non-residents have been instrumental in supplying much of the capital needed to build railways, canals, roads and other public utilities. They also played a major role in the development of new mineral deposits, some manufacturing industries and new sources of power. However, concerns as to foreign ownership of Canadian industry arose with the formation of the Canadian Pacific Railway.

Foreign investment made a large contribution to the Canadian economy prior to World War I. Much of the foreign capital imported before World War I was in the form of bonds sold to British bondholders. ${ }^{2}$ After the outbreak of World War I, the United States replaced the United Kingdom as Canada's major supplier of external capital. ${ }^{3}$ It was during this time period that a strong relationship between Canada and the United States fostered and grew with respect to foreign investment.

In 1911, Canadian Conservative Finance Minister W. C. Fielding and U.S. Secretary of State P. C. Knox concluded a free trade agreement between Canada and the United States whereby duties on certain goods were either reduced or eliminated. ${ }^{4}$ The U.S. Congress approved the agreement, but the next Canadian election saw the Conservatives defeated by the Liberals primarily based on public opposition to this agreement. As a consequence, the agreement was never put into force. ${ }^{5}$

R.S.C. 1985 , c. 28 (1st Supp) amended by 1988, c.65.

2. Melville H. Watkins, "Foreign Ownership and the Structure of Canadian Industry" (Ottawa: Privy Council Office 1968) (the Watkins Report) at 15.

3. Herb Gray, (The Honourable) "Foreign Direct Investment in Canada" (Ottawa: Information Canada 1972) (the Gray Report) at 13.

4. Peter Morici, "US-Canadian Trade Relations in the 1980s," (1987), XVII 2 American Review of Canadian Studies 159 at 173.

s. Ibid. at $\mathbf{1 7 4}$ 
Between 1914 and 1930, United States' direct and portfolio investment in Canada grew rapidly. ${ }^{6}$ A reasonably well developed capital market emerged in the post-World War II period. $^{7}$ In 1947 and 1948, Canada and the United States came close to instituting a free trade agreement for a second time. However, Canada's balance of payment pressures subsequently abated and Prime Minister King developed second thoughts about establishing such close economic ties with the United States. Both countries turned their attention towards the newly established General Agreement on Tariffs and Trade (GATT), where they became strong partners in advocating multi-lateral trade liberalization. ${ }^{8}$

\section{B. "KEY SECTOR" FOREIGN OWNERSHIP POLICY}

In the 1950s and 1960s, the federal government introduced amendments to legislation regulating what were perceived to be the "key sectors" of the Canadian economy, with the initial direction being toward financial institutions. The amendments focused on the nationality of directors and the ownership of shares.

The amendments were introduced into several federal statutes including: the Bank Act, the Canadian and British Insurance Companies Act, the Loan Companies Act, the Trust Companies Act and, subsequently, the Investment Companies Act. ${ }^{9}$ In addition, certain amendments were introduced into other federal and provincial statutes to control the ownership of shares in companies involved in other industries which were perceived to be "sensitive" by the federal and provincial governments, including, newspapers, broadcasting, transportation, securities and oil and gas.

During the 1950s and 1960s, foreign policy with respect to the oil and gas sector operated, for the most part, according to a pure market relationship: producers tried to serve the national market at fairly competitive prices while consumers resisted whenever supplies could be more cheaply or easily acquired from the United States. ${ }^{10}$ Difficulties arose as world oil prices were lower than those of Alberta, Canada's chief producer, and American demands were restrained by extensive domestic production. To protect the Canadian industry and to take advantage of cheaper international prices, the Canadian government divided the country into two oil zones along the so-called Ottawa Valley Line in 1961. An inter-provincial pipeline constructed in the 1950s served the Western zone providing slightly more expensive Canadian crude. Cheaper imported oil was supplied to the Eastern zone. Energy supplies surplus to Canadian needs were exported to the United States in an unrestrained manner throughout the 1960s."

While prices were low, this system produced little conflict. With the 1973 OPEC crisis, and a resulting four-fold increase in oil prices, the Alberta oil and gas industry

Gray supra, nole 3 at 13.

Watkins, supra, note 2 at 18.

Morici, supra, note 4 at 174.

Watkins, supra, note 2 at 384-388.

David Milne, "The Politics of Energy," Tug of War, 69 at 74.

lbid. at 74 . 
proved to have a multi-billion dollar potential. ${ }^{12}$ The response of the Trudeau minority government was to:

(i) freeze the domestic price of oil at a level well below the international bench mark;

(ii) to provide for a series of graduated increases in the price of oil;

(iii) to use revenue generated from an export tax on oil sold to the United States at world levels to pay for the increase costs of importing oil into Canada's Eastern oil zone; and

(iv) to set up a national oil company, Petro-Canada (formerly Petro-Canada Exploration Inc.), to help the Canadian state combat the uncertainties over energy supplies in the national interest. ${ }^{13}$

\section{FOREIGN INVESTMENT REVIEW ACT}

The Foreign Investment Review Act (Canada) ${ }^{14}$ ("FIRA"), which became law in December, 1973, was the first Canadian statute applying generally to foreign investment in Canada. ${ }^{15}$ It imposed controls and a review process for take-overs and new direct investments. The purpose of the legislation, set forth in subsection 2(1) of FIRA, was to enable "the ability of Canadians to maintain effective control over their economic environment." Its purpose was to be effected by ensuring that:

control of Canadian business enterprises may be acquired by persons other than Canadians ... only if it has been assessed that the acquisition of control of those enterprises or the establishment of these new businesses, as the case may be, by those persons is or is likely to be of significant benefit to Canada. ${ }^{\text {th }}$

In connection with the enactment of the FIRA legislation, there were two significant reports, the Watkins Report ${ }^{17}$ and the Gray Report ${ }^{18}$, with the latter forming the basis of the regulatory framework contained in FIRA. The Watkins Report examined the structure of the Canadian economy and the role of the foreign investor, especially the multi-national corporation. The report concluded, in part, that:

The major deficiency in Canadian policy has not been its liberality toward foreign investment per se but the absence of an integrated set of policies, partly with respect to both foreign and domestic firms, partly

lbid. at 75.

Ibid. at 76.

S.C. $1973-74$, c.46.

Robert Donaldson, and Craig Thorburn, "Foreign Investment in the 1990's in Canada. The Investment Canada Act" (Address to Insight seminar, 18 May 1989) at 3.

Harry S. Campbell, "Investment Canada and the Canadian Oil and Gas Industry." [1991] 21 C.C.L.R. 63 at 63.

Supra, note 3. 
with respect only to foreign firms, to ensure higher benefits and smaller costs for Canadians from the operations of multi-national corporations. ${ }^{19}$

In 1970, the Honourable Herb Gray was given the task of drawing up proposals on foreign investment policy for the then Liberal government. His objective was set forth in the Gray Report as follows:

to canvass the range of policy options that might enable Canadians:

(a) to exercise greater control over the national economic environment;

(b) to maximize the benefits and minimize the costs to Canada of foreign direct investment: and

(c) to retain and increase Canadian ownership of business activity where this is feasible or desirable for economic, social, cultural or other reasons. ${ }^{20}$

A strong nationalistic policy respecting foreign investment set the stage for FIRA. It was intended to dispense with the ad hoc tendencies of the past in favour of an atmosphere of certainty and predictability. It was hoped that FIRA could aggrieve the nationalistic sentiments and establish effective and workable guidelines and controls to provide certainty and continuity by which business transactions could be effected. It required foreigners to make application to the Foreign Investment Review Agency (the FIRA Agency) before acquiring control of a Canadian business or establishing a new business in Canada unrelated to an existing business. While the FIRA Agency considered and analyzed the application, the final decision on the take-over was made by the federal cabinet. To be allowed, the foreign take-over or new investment had to be of "significant benefit to Canada." ${ }^{21}$

\section{LIBERAL GOVERNMENT POLICY DURING THE EARLY 1980s}

\section{Expansion of Scope of FIRA}

Prime Minister Trudeau made it clear during the 1980 election campaign that a Liberal government would strengthen FIRA and expand the role of the FIRA Agency by: ${ }^{22}$

(i) establishing a monitoring system to review periodically the activities of large foreign-owned firms;

(ii) publishing large take-over bids by foreigners; and

(iii) making financial assistance, likely through loan guarantees, available to Canadian-controlled firms in Canada who want to compete with foreign firms for the take-over of Canadian business enterprises.

Supra, note 2 at 392.

Gray supra, note 3 at 9.

Donaldson, supra, note 15 at 10.

Ibid. at 15. 
In a February 12, 1980 pre-election speech to the Toronto Advertising and Sales Club Prime Minister Trudeau said:

\begin{abstract}
We want to expand and strengthen FIRA, not weaken it. FIRA's mandate will be broadened to include the periodic review of all foreign firms of large size to assess the performance of these companies in such areas as export promotion and research and development. FIRA will also be required to publicize proposed foreign take-overs beyond a certain size once they have been submitted to the Agency. This will encourage counter-offers from Canadian-controlled interests. Most importantly, through government guarantees of bank loans, FIRA will help provide financial assistance to Canadian companies that want to compete for foreign take-overs or repatriate foreign ownership of assets. ${ }^{23}$
\end{abstract}

\title{
2. National Energy Program
}

In his pre-election address, Prime Minister Trudeau also confirmed the Liberal government's position respecting the Canadian energy sector. He indicated that a Liberal government would start at once to:

...capitalize on Canada's energy base in order to build a world competitive sector... ${ }^{24}$

and:

...to promote the creation and expansion of independent Canadian owned enterprises. We want Petro-Canada to work closely with the independents, and one of our goals is an all.Canadian tarsands plant...Finally, Liberals want to expand Canadian ownership and control. We have already stated that our goal in the oil and gas industry is $50 \%$ Canadian ownership by the end of the decade. But as I have tried to make clear today, the central element in our strategy is to focus on future developments. We will ensure that the booming energy sector will be majority Canadian-owned. We will use the federal govermment's regulatory and purchasing power to encourage Canadian firms and channel Canadian savings into new investment opportunities. ${ }^{25}$

On October 28, 1980, the federal government introduced the National Energy Program (NEP). The NEP stressed the national dimensions of the policy at the outset:

This is a set of national decisions by the Government of Canada. The decisions relate to energy. They will impinge, however, on almost every sphere of Canadian activity, on the fortunes of every Canadian, and on the economic and social structure of the nation for years to come. They have major, positive implications for the federation itself. ${ }^{26}$

One of the objectives of the Energy Strategy for Canada, published by the government of Canada in 1976, was to substantially increase Canadian ownership of the petroleum sector. When it introduced the NEP, the government expressed concern that: 
...while there has been some reduction in the level of foreign ownership of the industry, the objectives

have not been met. ${ }^{27}$

The NEP documented, as a clear objective of the policy of the government of Canada, greater Canadian ownership of the oil and gas industry. The government of Canada stated that the oil and gas sector was a unique case and that special measures, not required in other sectors were needed to ensure more Canadian control. The government wished to encourage private Canadian firms to acquire some of the foreign-controlled oil and gas companies. Accordingly, the NEP contained a number of measures designed to increase Canadian participation and private ownership. The NEP suggested three goals: ${ }^{28}$ at least $50 \%$ Canadian ownership of oil and gas production by 1990 ;

$$
\text { Canadian control of a significant number of the larger oil and gas firms; }
$$

an early increase in the share of the oil and gas sector owned by the government of Canada.

Amendments to the constrained share provisions of the Canada Business Corporations $A c t^{29}$ and the Canada Business Corporations Regulations ${ }^{30}$ were introduced to allow federally incorporated oil and gas companies to control their own Canadian ownership rate status required to qualify for petroleum incentive payments under the NEP, by arbitrarily selling shares of non-Canadian shareholders without shareholder consent, and by purchasing their own shares on the open market and holding them for up to two years. During this time they could be resold as restricted shares, which could only be sold to and held by Canadians or Canadian-controlled companies.

It is important to note that the NEP directed the FIRA Agency to block any attempts by foreign oil companies to take over Canadian enterprises, while at the same time it exposed foreign oil companies to massive takeover attempts by Canadian capital. ${ }^{31}$ To effect such a result, the requirements of majority Canadian ownership and control in oil and gas by 1990 were set out, the tax system was rearranged so that depletion allowances for foreign-owned oil companies would be reduced and then eliminated, while overly generous incentive grants would be provided to companies meeting Canadian ownership and control requirements and the share of economic rents enjoyed by foreign oil companies was curtailed. The result of these policies was a rise in Canadian ownership levels, as well as Canadian corporate debt. ${ }^{32}$

The other essential part of the Liberal's political policy in energy was to ensure that the federal government received a much larger share of oil and gas revenues. The federal

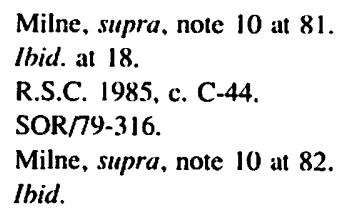


government intended to move its share of the total revenues from oil and gas production to $24 \%$ by 1983 , due significantly to the introduction of new taxes on oil and gas. ${ }^{33}$ On September 1, 1981, a new energy pact was signed; this agreement saw Alberta sanction the new federal share of revenues largely in return for a higher projected price structure for oil and gas and for a federal withdrawal from its natural gas export tax. ${ }^{34}$ In the four years following the introduction of the NEP, Canadian ownership of upstream production revenues increased from 28 percent to 40 percent. ${ }^{35}$ Foreign owned companies, however, continued to dominate the industry.

\section{The Softening Stance}

In early 1981, the U.S. Secretary of Commerce criticized the jurisdiction of FIRA, the FIRA Agency policy and conditions imposed by the FIRA Agency in undertakings. The U.S. Secretary of State argued that it was objectionable that corporations be required to do the following: ${ }^{36}$

(i) promise their banking business to Canadian banks;

(ii) use Canadian advertising agencies;

(iii) deal with Canadian public accountants;

(iv) procure a specific percentage of their requirements in Canada;

(v) reduce equity shares in both Canadian firms being acquired and in other unrelated operations in Canada;

(vi) pledge to stop importing certain products;

(vii) move manufacturing operations from the United States to Canada;

(viii) agree to export specific products;

(ix) furnish technology, trademarks, etc. free of charge to their Canadian subsidiaries; and make "financial contributions" to a Canadian project in which it held no interest.

Proceedings were commenced against Canada by the United States under the GATT claiming that under FIRA, U.S. investors were improperly coerced into switching purchases to Canadian sources and into exporting from Canada. As a result of these 
proceedings, the government changed its policy and only requested that FIRA applicants give Canadian suppliers a full and fair opportunity to supply them. ${ }^{37}$

By late 1981 there was evidence to suggest that the federal government decided, at least for the present, to soften its approach. The November 12, 1981 Budget included a specific reference to the "Ownership of Canadian Industry." Firstly, the government indicated:

The special measures being employed to achieve more Canadian ownership and control of the oil and gas industry are not, in the Government of Canada's view, appropriate for other sectors. ${ }^{38}$

Secondly, regarding the proposals to strengthen FIRA:

In the Speech from the Throne in the spring of 1980 , reference was made to three specific measures, two of which involved changes to the Foreign Investment Review Act. For the time being, no legislative action is intended on these measures until progress on the major initiatives already undertaken by the government has been assured. ${ }^{39}$

By 1982, the legislative framework of FIRA, the review process, and many of the other federal initiatives aimed at regulating the activities of foreigners in Canadian business, in general the Canadianization process, resulted in strained business relationships with many foreign governments, particularly the United States. It was clear that the policies of the Liberal government in the 1970's alienated foreign corporations in the oil and gas sector.

\section{E. INTRODUCTION OF THE INVESTMENT CANADA ACT}

During the 1984 election campaign, the Conservative party campaigned on the basis that it would welcome foreign investment to make Canada "once again ... a first class place to invest" ${ }^{40}$ and that it would change the name of the FIRA Agency to Investment Canada "which will be more indicative of its changed mandate to take on a more positive role in international investment." ${ }^{41}$

Following their election to power on September 4, 1984, the Conservative party gave the first indication of the changes that it was planning with respect to FIRA and the NEP. The re-christened Agency would be restricted to major investment proposals of national economic significance only. The NEP would be changed to end the retroactive and excessive discrimination that the program had inflicted on foreign-owned companies since its inception in $1980 .^{42}$ A tax-based incentive system was devised to replace the then present system of grants. The Minister of Finance told a meeting of the International Monetary Fund:

$\begin{array}{ll}\text { 37. } & \text { Ibid. at } 21 . \\ \text { 3x. } & \text { Ibid. } \\ \text { 39. } & \text { Ibid. at } 22 . \\ \text { 40. } & \text { Ibid. } \\ \text { 41. } & \text { Ibid. at } 23 . \\ \text { 42. } & \text { Ibid. }\end{array}$


Canada's 'welcome mat' is out once more for foreign investment - Canada is a good place to do business; we are opening our doors to those who want to share in the tremendous opportunities with which we have been endowed. ${ }^{43}$

The November 5th, 1984 Speech from the Throne reflected this new approach:

Initiatives will be taken to stimulate both domestic and foreign investment. My government is determined to regain Canada's reputation as a reliable and profitable place to do business."

On December 7th, 1984, Bill C-15, An Act Respecting Investment in Canada, received first reading in the House of Commons. ${ }^{45}$ The Investment Canada Act was introduced in December of 1984 and came into effect on June 30, 1985.

The introduction of the ICA in 1984 was the first significant step evidencing a change of government policy on foreign investment. The purpose of the new legislation, in sharp contrast to FIRA, is identified in section 2 of the Act:

Recognizing that increased capital and technology would benefit Canada, the purpose of this Act is to encourage investment in Canada by Canadians and non-Canadians that contribute to economic growth and employment opportunities and to provide for the review of significant investments in Canada by non-Canadians in order to ensure such benefit to Canada.

In addressing the Standing Committee on Regional Economic Development concerning the Investment Canada Bill on February 5, 1985, The Honourable Sinclair Stevens, the then Minister of Regional Industrial Expansion and Minister Responsible for the Administration of FIRA and, shortly thereafter, the ICA, stated:

One of the lessons our economic history has taught us is that Canada has prospered most when the country has been open to trade and investment with the rest of the world. The periods of greatest protectionism in this country have coincided with periods of stagnation and recession.

We believe that in today's international economic context and, indeed, for the foresecable future, international partnerships and investments, where Canadians and non-Canadians work together in Canada and abroad, can be very beneficial to Canada.

The factors of assessment, on which the Minister's decision to allow or disallow an investment must be based, are similar to those specified in the Foreign Investment Review Act, with two exceptions. As I said earlier, a cultural policy component has been added to the fifth factor, so that it now reads:

-The compatibility of the investment with national industrial, economic and cultural policies, taking into consideration industrial, economic and cultural policy objectives enunciated by the government or legislature of any province likely to be significantly affected by the investment."

Ibid.

44. Canada, House of Commons Debates, Speech from the Throne, No. 128 at 6 (5 November 1984).

45. Bill C-15, An Act Respecting Investment in Canada, at 1010 (7 December 1984). 
The addition of the cultural policy component shows our appreciation of the special consideration which must be given to cultural industries.

The second difference between the factors of assessment in the current legislation and in Bill C-15 is the addition of a sixth factor, as follows:

'The contribution of the investment to Canada's ability to compete in world markets.'

In introducing the ICA, the Minister stated that encouragement and facilitation of investment in Canada by non-Canadians and Canadians alike, was an important government objective:

This positive mandate is the heart of the Investment Canada Bill - we believe that in today's international economic context and indeed, for the foreseeable future, international partnerships and investments where Canadians and non-Canadians work together in Canada and abroad, can be very beneficial to Canada. ${ }^{47}$

\section{F. CONTINUING RESTRICTIONS IN THE OIL AND GAS SECTOR}

The ICA, as first proclaimed, did not isolate the oil and gas industry as a sensitive investment area. Notwithstanding the neutrality of the Act, the amendments effected by the Free Trade Agreement ${ }^{48}$ (FTA), discussed in more detail below, confirm that such investments are subject to special treatment. A long time policy of the federal government has been Canadian ownership of the oil and gas industry in the amount of $50 \%$ before the end of the 1980 s.

This position survived the change of governments from the Liberals to the Progressive Conservatives in 1984. As a means to the end, it has become a policy of the federal government to forbid the direct acquisition of "healthy" Canadian-controlled businesses with assets of at least $\$ 5$ million, notwithstanding that such an acquisition may likely be a net benefit to Canada. In an exchange of letters in connection with the Free Trade Agreement between the Honourable James A. Baker III, Secretary of the Treasury of the United States and the Honourable Michael H. Wilson, the Minister of Finance, Canada's published policies respecting acquisitions in Canada's oil and gas industry were confirmed as follows:

In reviewing acquisitions, the Minister responsible for Investment will:

(a) disallow the direct acquisition of a healthy Canadian-controlled business with assets of at least $\$ 5$ million;

(b) consider allowing the direct acquisition of a Canadian-controlled business with assets of at least $\$ 5$ million that is in clear financial difficulty. In such cases the Minister would review the

Donaldson, supra, note 15 at 25.

Ibid.

The Canada-United States Free Trade Agreement, December 11, 1987. 
proposed foreign acquisition to evaluate its net benefit to Canada and could negotiate, as necessary, undertakings by the acquirer in relation to the review criteria;

(c) normally allow the direct acquisition of a forcign-controlled business with assets of at least $\$ 5$ million, subject to an agreement with the acquirer on conditions related to Canadian ownership and investment spending; and

(d) normally allow the indirect acquisition of a foreign-controlled business with assets of at least $\$ 50$ million, subject to an agreement with the acquirer on conditions related to Canadian ownership and investment spending. ${ }^{49}$

The foregoing is currently the official policy governing investments in Canada's oil and gas industry. According to Michael Cleland, Director General, Energy Policy Branch, Department of Energy, Mines and Resources (Ottawa) ${ }^{50}$ at the end of 1989, 43.4\% of the industry is owned by Canadians and 33\% is Canadian-controlled. As will be discussed in greater detail in Part IV below, the policy is being applied and the Act is being interpreted so as to provide considerable flexibility to investors.

\section{G. CONTRAST BETWEEN ICA AND FIRA}

The ICA resulted in a significant departure from the rules under FIRA. For example:

(i) decisions are now made on a net benefit to Canada test whereas under FIRA, investments were disallowed unless they were of significant benefit to Canada;

(ii) other than investments related to Canada's cultural heritage or national identity, most new business investments and a number of specific acquisition transactions are exempt from review;

(iii) only acquisitions by non-Canadians of assets exceeding $\$ 5$ million, with significantly higher thresholds in non oil and gas investments by Americans, are reviewable; and

(iv) the Minister, not the Federal Cabinet, makes most decisions and the ICA imposes constraints on the time allowed for the decisions to be made.

\section{H. CONCLUSION}

FIRA was used as a tool to carry out the policies of the federal government, especially in those business sectors perceived by governments to be sensitive, where there were no specific statutory provisions to ensure Canadians would be able to maintain control. Before the ICA was implemented, the federal government, through the enactment of legislation and the promulgation of policies, most notably FIRA and the NEP, embarked

49. ICA, Guidelines under the Free Trade Agreement.

so. Michael Cleland, "Policy Towards Foreign Investment in the Oil and Gas Industry" (Address to Insight seminar, 27 February 1991). 
upon a Canadianization program. Both provincial and federal governments continued to enact specific legislation to limit the ownership by foreigners in sensitive areas of Canadian business.

By 1982, economic conditions in Canada had changed dramatically. Canada was in a recession. The international investment climate had changed dramatically. By the end of 1984, the Canadian government had changed and the globalization of markets resulted in an increasingly competitive economic environment. In an attempt to deal with these changes, FIRA and the NEP were scrapped and a streamlined ICA was passed to encourage investment in Canada by Canadians and non-Canadians.

The ICA will continue to be used as one of the principal tools of the government's economic policy to control and regulate foreign investment in Canada. The net benefit criteria are subjective so that governments can exercise considerable latitude in the review process.

In the protected upstream oil and gas sector 50\% Canadianization continues as the policy objective.

\section{OVERVIEW OF THE INVESTMENT CANADA ACT}

\section{A. PURPOSE}

The ICA, proclaimed June 30, 1985 after the election of the Progressive Conservative government of Brian Mulroney in September, 1984, replaced the FIRA and is now the umbrella act governing foreign investment in Canada. Its purpose is to encourage investment in Canada by Canadians and non-Canadians that contributes to economic growth and employment opportunities and to provide for the review of significant investments in Canada by non-Canadians in order to ensure such benefit to Canada. ${ }^{51}$

\section{B. EXEMPT INVESTMENTS}

Part II of the ICA exempts many investments which might otherwise be caught by the legislation. The existence of an exemption is a bar to the application of the notice and review provisions of the ICA. The exemptions are found in section 10. Each exemption relates to a transaction in which the person gaining control of a Canadian business does not seek control as an end in itself, but acquires control inadvertently or in furtherance of another goal. The key exemptions are as follows:

(i) trader - the acquisition of voting interests by a trader or dealer in securities in the ordinary course of its business;

(ii) venture capitalists - the acquisition of voting interests by a person in the ordinary course of a venture capital business; 
(iii) realization of security - the acquisition of control of a Canadian business through the realization of a security granted for a loan or other financial assistance (in Opinion No. 19 issued October 29, 1985 pursuant to section 37 of the ICA, the scope of this exemption has been interpreted in a broad manner);

(iv) repatriation of control - the acquisition of control of a Canadian business for the purpose of bona fide facilitation of the financing of such business, provided, however, the investor divests control within two years or such longer period as approved by the Minister;

(v) reorganization - the acquisition of control of a Canadian business by reason of an amalgamation, a merger, a consolidation or other corporate reorganization involving no ultimate change of control;

(vi) government businesses - with some minor exceptions, the acquisition of control of a Canadian business carried on by the federal or a municipal or provincial government, an agency thereof or a Crown corporation;

(vii) banking - the acquisition of control or establishment of a bank or a foreign bank subsidiary and certain related banking transactions which are covered by other federal legislation;

(viii) involuntary acquisitions - the involuntary acquisition of control of a Canadian business on the death of the owner or by operation of law;

(ix) farm businesses - the acquisition of control of a Canadian farming business provincial legislation governs the acquisition of farm property by non-Canadians; and

(x) certain passive investments - relating to acquisitions of control of a Canadian business by Canadian based insurance companies for the benefit of their Canadian policyholders.

\section{NOTIFIABLE INVESTMENTS}

The ICA, in Part III, requires that notice be given to Investment Canada of any investment by a non-Canadian to establish a new Canadian business or acquire control of a Canadian business, except in circumstances where the investment is a reviewable investment because the investment is over a prescribed dollar amount or is related to Canada's cultural heritage or national identity, or is an investment to which the ICA does not apply. "Non-Canadian" and "acquisition of control" will be discussed with respect to reviewable investments. 
The notification must be made either before the investment is implemented or within 30 days thereafter. ${ }^{52}$ Once Investment Canada has received the notification or sufficient reasons for the inability to provide any part of the information required in the notification, it is required to issue a receipt certifying the date on which the notice was received and advising the non-Canadian that the investment is not reviewable, or, unless Investment Canada issues a notice of review within 21 days after the certified date of the receipt, the investment is not reviewable. ${ }^{53}$

The establishment of a new Canadian business by a non-Canadian is a notifiable transaction under section 11 of the ICA. A new Canadian business is defined in section 3 as a business that is not already being carried on in Canada by the non-Canadian and that, at the time of its establishment, is unrelated to any other businesses being carried on in Canada by the particular non-Canadian, or is related to another business being carried on in Canada by the non-Canadian, but falls within a prescribed specific type of business activity that, in the opinion of the Governor in Council, is related to Canada's cultural heritage or national identity.

In guidelines issued by the Minister under the authority of section 38 of the ICA, it is provided that the expansion of an existing business, or the establishment of a related new Canadian business which is not within a type of business activity referred to above, is not subject to either the notification or review provisions of the ICA. ${ }^{54}$ Further, the guidelines provide that an expansion or reorganization of an existing business, merely because of new premises, new personnel or internal reorganization, is not considered to be the establishment of a new business. ${ }^{55}$ Further, a new business activity commenced by an investor is regarded as the expansion of an existing business, rather than the establishment of a new business, if the new activity produces goods or services which are substantially similar to the goods or services produced by the existing business or if all of the goods or services produced by the new business are used in carrying on its existing business. ${ }^{56}$ The guidelines go on to set forth principles which will aid in interpreting whether a new business is related to an existing business. Such principles include vertical integration, import substitution, product substitution, similar technology, research and development, industry sector and a general principle. ${ }^{57}$ These principles should be reviewed in making any determination as to whether a new business is related to an existing business.

\section{REVIEWABLE TRANSACTIONS}

The main thrust of the ICA is Part IV, which focuses on reviewable transactions. The investment rules pertaining to such transactions can be summarized as follows:

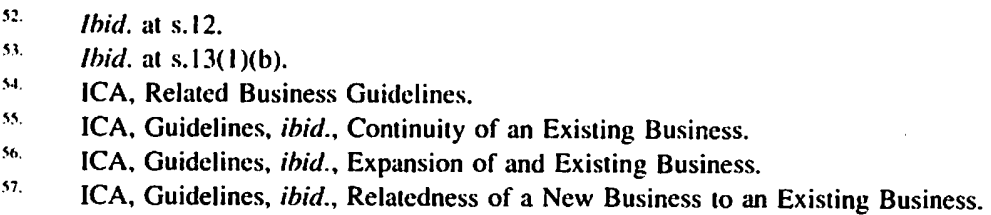


An investment, which is not exempt, by a non-Canadian, as defined in the ICA, to acquire control. in a manner specified, of a Canadian business, as defined, the assets of which are over a statutorily prescribed threshold value which varies, depending on whether the non-Canadian is an American and depending on the nature of the Canadian business if the non-Canadian is an American, or a Canadian business which is involved in an activity related to Canada's cultural heritage or national identity, as prescribed, is a reviewable transaction requiring a determination by the Minister, within a limited time frame, that such investment is likely to be of net benefit to Canada before. other than in limited exceptions, it will be permitted to be carried out. ${ }^{58}$

The underlined concepts are explained below.

\section{Non-Canadian}

The ICA does not apply to investments by Canadians. The term "non-Canadian" is defined in section 3 of the ICA to mean an individual, government, government agency or entity, being a corporation, partnership, trust or joint venture, that is not a Canadian. A "Canadian" is defined as: ${ }^{59}$

a Canadian citizen;

(ii) a permanent resident of Canada, ordinarily resident in Canada, who has been eligible to apply for Canadian citizenship for no more than one year;

(iii) the federal, a provincial, or a local government in Canada, or an agency thereof; and

(iv) a Canadian-controlled entity.

A complicated set of rules in section 26 are applicable to the determination of whether a corporation, partnership, trust or joint venture is Canadian-controlled. For the purpose of these rules, a "voting group" has been defined in section 3 to mean, in essence, two or more persons who are associated in such a way that they would ordinarily be expected to act together on a continuing basis in the exercise of their voting rights.

Section 26 sets forth the principles to be used in determining whether an entity is Canadian, a summary of which follows:

(i) if a majority of the voting interests in an entity is owned by one Canadian, or by two or more Canadian members of a voting group, the entity is Canadian-controlled; ${ }^{60}$ 
(ii) conversely to (i), an entity is not Canadian-controlled if one non-Canadian, or two or more non-Canadian members of a voting group, own a majority of the voting interests; ${ }^{61}$

(iii) if (i) and (ii) do not apply, and if a majority of the voting interests is owned by Canadians, and it can be shown that the entity is not controlled in fact by one non-Canadian or by a voting group in which one or more non-Canadians own one-half or more of the voting interests owned by the voting group, then the entity is Canadian-controlled; ${ }^{62}$

(iv) if (i), (ii) and (iii) do not apply, and less than a majority of the voting interests are owned by Canadians, an entity is presumed not to be Canadian-controlled, unless it can be shown that either the entity is controlled in fact through the ownership of voting interests by one Canadian or by a voting group in which Canadians hold a majority of the voting interests owned by the voting group, or for corporations or limited partnerships, that the entity is not controlled in fact through the ownership of voting interests and two-thirds of the board of directors or general partners are Canadians; ${ }^{.3}$

(v) a trust is deemed to be Canadian if it is established that it is not controlled in fact through the ownership of its ownership interests and two-thirds of the trustees are Canadians; ${ }^{64}$

(vi) a Canadian corporation which has its voting shares publicly traded is deemed to be Canadian for the purpose of making investments which are not related to Canada's cultural heritage or national identity if the Minister is satisfied that the majority of its voting shares are owned by Canadians, four-fifths of the members of its board of direciors are Canadian citizens ordinarily resident in Canada, its chief executive officer and three of its four most highly remunerated officers are Canadian citizens ordinarily resident in Canada, its principal place of business is located in Canada, its board of directors supervises the management of its business and affairs on an autonomous basis without direction from any shareholder other than through the normal exercise of voting rights at meetings of its shareholders, and these circumstances have existed for at least twelve months. The deemed Canadian status will lapse the earlier of two years following the date of notification from the Minister of the deemed Canadian status under subsection 26(3) and the date the material facts submitted to the Minister in connection with this matter change substantially; ${ }^{65}$ 
(vii) if a non-Canadian and a Canadian each own $50 \%$ of the voting shares of a corporation, it is not Canadian-controlled; ${ }^{66}$

(viii) any voting bearer shares of a corporation are deemed to be owned by non-Canadians unless the contrary is established; and ${ }^{67}$

(ix) holders of voting interests which own less than $1 \%$ of the voting interests in an entity, in the absence of evidence to the contrary, are deemed Canadian if an official of the entity certifies that such holders have Canadian addresses and that such official has no reason to believe that such voting interests are owned other than by Canadians. ${ }^{68}$

Section 37 allows a person to apply to the Minister for an opinion as to whether that person is a Canadian for the purposes of the ICA and the Minister can give a binding opinion lasting for as long as the material facts on which the opinion was based remain substantially unchanged. A discussion of the relevant ministerial opinions in the context of the oil and gas industry will follow.

\section{Acquisition of Control}

Under subsection 14(1), an investment by a non-Canadian is reviewable only if it involves an acquisition of control of a Canadian business. Under section 28, a non-Canadian acquires control of a Canadian business "only" by:

(i) the acquisition of voting shares of a Canadian-incorporated corporation carrying on a Canadian business; ${ }^{69}$

(ii) the acquisition of voting interests of an entity that carries on a Canadian business or that controls, directly or indirectly, another entity carrying on a Canadian business where there is no acquisition of control of a corporation; ${ }^{70}$

(iii) the acquisition of all or substantially all of the assets used in carrying on a Canadian business; ${ }^{71}$ or

(iv) the acquisition of voting interests of an entity that controls, directly or indirectly, an entity in Canada carrying on a Canadian business, including an acquisition of a non-Canadian entity outside Canada which controls, directly or indirectly, an entity in Canada carrying on a Canadian business - for example, the indirect acquisition of a Canadian business carried on by a Canadian subsidiary through 
the share acquisition outside Canada of its U.S. parent is an acquisition of control for the purposes of the ICA. ${ }^{72}$

Interpretation Note No. 3 issued by the Minister pursuant to section 38 of the ICA identifies factors which are taken into account in making a determination of what constitutes "substantially all" of the assets used in carrying on a Canadian business. In the interpretation note, it is confirmed that the determination is not purely a quantitative one based solely on the proportionate value or number of assets to be acquired or retained by the vendor. For example, if an asset essential to the continuance of the business is not acquired, Investment Canada will find that, notwithstanding the fact that all other assets of the business are acquired, control of the business is not acquired. Assets essential to the continuance of a business are held to be those assets without which the business cannot reasonably be expected to be carried on.

Under subsection 28(3)(a), the acquisition of a majority of the voting interests in an entity is deemed to be the acquisition of control of that entity. Accordingly, the purchase of more than $50 \%$ of the voting shares of a corporation is an acquisition of control of that corporation. The ICA concerns itself with a majority of votes in connection with the acquisition of shares to cover circumstances where one class of a corporation's shares carries fractional voting rights for each share or more rather than a single vote per share.

Subsection 28(3)(c) of the ICA provides that the acquisition of one-third or more of the voting shares of a corporation is presumed to be the acquisition of control of that corporation, unless it can be established that, on the acquisition, the corporation is not controlled in fact by the investor through the ownership of voting shares. Subsection 28(3)(d) confirms that the acquisition of less than one-third of the voting shares of a corporation is deemed not to be an acquisition of control of such corporation.

Finally, the one-third rule, applicable to corporations, is not applicable to other entities. Subsection $28(3)$ (b) provides that the acquisition of less than a majority of the voting interests of an entity other than a corporation is deemed not to be an acquisition of control of such entity.

Section 29 sets forth a "series of transactions" rule. An acquisition of control includes an acquisition resulting from more than one transaction or event whether or not related, and whether or not any of such transactions or events occurred before the ICA came into force.

Finally, it is provided in section 30(1) that a non-Canadian which has an option or absolute right to acquire voting interests in an entity, or assets used in carrying on a business, will not be treated for the purposes of the ICA as having acquired such voting interests or assets unless such non-Canadian elects to be so treated. The non-Canadian may elect to have the transaction reviewed immediately as an acquisition of control or may wait until the option is to be exercised. 


\section{Canadian Business}

In section 3, the ICA defines "business" as including any undertaking or enterprise capable of generating revenue which is being carried on in anticipation of profit. Subsection 31(2) extends the meaning of a business to include a part of a business that is capable of being carried on as a separate business.

In Interpretation Note No. 2, the Minister has listed factors which Investment Canada may find relevant to a determination as to whether a part of a business is capable of being carried on as a separate business. These factors include:

(i) does the part have separate accounting mechanisms, management, advertising, selling, purchasing, delivery, customers, or an identifiable group of employees;

(ii) are the operations of the part carried on under a separate license, patent or similar right;

(iii) is the part carried on in separate premises or are the physical assets of the part segregated from the other business operations of the vendor; and

(iv) does the part supply or provide some service which is more than purely incidental or ancillary to the main business operations of the vendor?

In Interpretation Note No. 4, the Minister has clarified what does and does not constitute a business. For example, market research, test marketing or feasibility studies by themselves have been determined to not constitute a business because they are not activities capable of generating revenue. If an undertaking or enterprise is in a pre-operational state due to the lack of an essential assets, source of supply or manpower, it is not considered to be a business within the meaning of the ICA. Further, profit-making, be it in the near future or distant future, must be a purpose of the undertaking or enterprise.

In connection with oil and gas properties, a property upon which only exploration for oil or gas has been conducted is not considered to be a business. However, a property which contains oil or gas reserves is considered to be a business if production of oil or gas is actually occurring or if it has been determined that the property contains economically recoverable quantities of oil or gas and the drilling of a well to recover such oil or gas for the purpose of production has been commenced. The trigger point is the commencement of drilling. The subsequent temporary shutting-in of production from a property will not result in a reclassification of the property as a non-business. ${ }^{73}$

A similar position is adopted in connection with mining properties. Mineral properties which are only at the exploration stage are not considered to be businesses. On the other hand, a producing mine is considered to be a business as is a property on which 
development of a mine has been commenced and the temporary closure of a mine will not change the classification of the mineral property as a business. ${ }^{74}$

Further clarification is found in section 3 where a business is classified as a "Canadian business" if:

(i) it is carried on in Canada;

(ii) it has a place of business in Canada;

(iii) it has one or more individuals in Canada who are employed or self-employed in connection with the business; and

(iv) it has assets in Canada used in carrying on the business.

In subsection 31(1), a Canadian business is deemed to be carried on in Canada notwithstanding that it is carried on partly in Canada and partly in some other place.

4. Thresholds for Reviewable Investments

(a) Non-Canadians Other Than Americans

Pursuant to section 14 and subsection 28(1) of the ICA, the following investments by non-Canadians require review:

(i) a direct acquisition of control by a non-Canadian of a Canadian business having assets of $\$ 5,000,000$ or more;

(ii) an indirect acquisition by a non-Canadian of a Canadian business which has assets, when combined with all other entities in Canada, the control of which is acquired, directly or indirectly, is $\$ 50,000,000$ or more, provided however, subsection 14(2) lowers the threshold to $\$ 5,000,000$ if the assets of the Canadian business represent more than $50 \%$ of the total value of the assets acquired in the international and domestic transaction; and

(iii) an investment, including the establishment of a new business, as well as an acquisition of control which falls within specific categories of business activity prescribed by Cabinet as "related to Canada's cultural heritage or national identity" is reviewable at the discretion of Investment Canada, no matter what the value of the transaction is.

The manner of calculating the value of assets is prescribed by section 3 of the ICA Regulations ${ }^{75}$ to be the aggregate of all assets acquired or of all assets of the entity as

3. SOR/85-611 amended by SOR/89-69, s. 3(5). 
shown in the audited financial statements for the entity carrying on the business for its fiscal year immediately preceding the implementation of the investment. Subsection 3(5) of the ICA Regulations exempts the requirement that the value shown on audited financial statements be used as a determinant in circumstances where they are not ordinarily prepared. In these circumstances unaudited financial statements can be used.

Americans

The FTA affects investments by American investors in Canadian businesses in three important ways. First, specific changes to the ICA and its regulations are effected by the FTA. Second, specific changes to various federal acts which regulate the percentage of voting shares of financial institutions which may be owned by Americans are mandated. For example, the rules which limited the aggregate voting share ownership by Americans to $25 \%$ in federal financial sector legislation are eliminated. Third, the FTA more or less freezes restrictions on U.S. investors in Canadian businesses at their current levels, commonly known as grandfathering. ${ }^{76}$ The discussion herein will focus solely on the changes mandated to the ICA.

The ICA is grandfathered, that is, even though it currently restricts investment by U.S. investors in Canadian businesses, the ICA is specifically continued in force, with few changes. The Canada-United States Free Trade Agreement Implementation Act (Canada) $^{77}$, is the federal legislation which amends various federal statutes so that they comply with the requirements of Canada under the FTA. Sections 135 through 137 of that Act amend the ICA to comply with the obligations of Canada found in Annex 1607.3 of the FTA. The regulations to the ICA have also been amended.

The only type of person or entity able to take advantage of the liberalized treatment of U.S. investments in Canadian businesses is an "American," defined, in much the same way as a Canadian, in subsection 14.1(9) of the ICA as:

(a) an individual, other than a Canadian, who is a national of the United States or is lawfully admitted for permanent residence, within the meaning given those expressions in the Immigration and Nationality Act of the United States;

(b) a government of the United States, whether federal, state or local, or an agency thereof;

(c) an entity that is not a Canadian-controlled entity, as determined pursuant to subsection 26(1) or (2), and that is an American-controlled entity, as determined in accordance with subsection 14.1(10);

(d) a corporation or limited partnership

(i) that is not Canadian-controlled, as determined pursuant to subsection 26(1). 
(ii) that is not an American within the meaning of paragraph (c),

(iii) of which less than a majority of its voting interests are owned by Americans,

(iv) that is not controlled in fact through the ownership of its voting interests, and

(v) of which two thirds of the members of its board of directors, or of which two thirds of its general partners, as the case may be, are any combination of Canadian and American: or

(e) a trust

(i) that is not Canadian-controlled, as determined pursuant to subsection 26(1) or (2),

(ii) that is not an American, within the meaning of paragraph (c),

(iii) that is not controlled in fact through the ownership of its voting interests, and

(iv) of which two thirds of its trustees are any combination of Canadians and Americans.

Subsection 14.1(10) provides that the tests for determining whether an entity, referred to in subsection (c) of the definition, is American-controlled are the same as the tests for determining whether an entity is Canadian-controlled, as discussed above, except that the word "American" is substituted for the word "Canadian" in the tests.

Given that the determination of what is an American is a fairly complex test, subsection 37(1) provides that the Minister will make a determination as to whether an individual or entity is an American and will provide a binding opinion in connection therewith.

Subsection 14.1(1) provides that an investor who qualifies as an American and who proposes to make an investment in a Canadian business is subject to higher thresholds before the investment is reviewable. Further, subsection 14.1(1) allows an investor from a third country to take advantage of the higher thresholds in an indirect acquisition of a Canadian business if immediately prior to the implementation of the investment by the third country investor, the Canadian business being indirectly acquired by the investor is controlled by an American.

With respect to a direct acquisition of control by or from an American, subsection 14.1(2) sets the new thresholds for review as follows:

(a) at any time in $1989, \$ 25$ million;

(b) at any time in $1990, \$ 50$ million;

(c) at any time in 1991, $\$ 100$ million:

(d) at any time in 1992, $\$ 150$ million; and

(e) at any time in each year after 1992, an amount for that year equivalent to $\$ 150$ million in constant 1992 dollars, as determined in accordance with a formula based on the GDP Price Index prepared by Statistics Canada. ${ }^{7 x}$ 
With respect to an indirect acquisition of control by or from an American, under subsection 14.1(6) the new thresholds are as follows:

(a) at any time in 1989, $\$ 100$ million;

(b) at any time in 1990, $\$ 250$ million; and

(c) at any time in 1991, $\$ 500$ million.

After January 1, 1992, subsection 14.1(7) provides that an indirect acquisition of control by or from an American is not subject to review under section 14 at all.

\section{Nature of the Canadian Business}

Under the FTA, it was agreed that certain industries would not be subject to the acquisition provisions. Accordingly, subsection 14.1(8) of the ICA provides that the new thresholds are not applicable to certain industries with the effect that the existing thresholds continue to apply to Americans. Canadian businesses to which the new thresholds do not apply are as follows:

(i) oil and gas: businesses engaging in the development or production of oil or natural gas and owning an interest in proven reserves of oil or natural gas in Canada, ${ }^{79}$

(ii) uranium: businesses engaging in the production of uranium and owning an interest in a producing uranium property in Canada; ${ }^{\mathrm{x}(1)}$

(iii) financial services: businesses providing any financial service; ${ }^{81}$

(iv) transportation services: businesses providing any transportation service; ${ }^{82}$ or

(v) culture: cultural businesses. ${ }^{83}$

Interpretation notes, opinions and decisions by Investment Canada limit the scope of the oil and gas exception.

\section{Reviewable Transactions}

Where a transaction is reviewable under Part IV of the ICA, subsection 17(1) requires the non-Canadian making the investment to file an application with Investment Canada containing information as prescribed. The application may be filed at any time prior to the implementation of the investment. ${ }^{84}$ However, in cases where an investment is made 
through an indirect acquisition of an entity that controls, directly or indirectly, an entity in Canada carrying on a Canadian business pursuant to subsection 28(1)(d) or in circumstances where the Minister has sent a notice pursuant to subsection $16(2)$ to the non-Canadian making an investment to the effect that the Minister is satisfied that a delay in implementing the investment would result in undue hardship to the non-Canadian or would jeopardize the operations of the Canadian business that is subject to the investment, the application may be sent at any time prior to the implementation of the investment or within 30 days thereafter. ${ }^{85}$

Upon receiving an application for a review containing the required information, or reasons for the inability to provide any part of the required information, Investment Canada has a positive duty to send the applicant either a receipt certifying the date of receipt or a notice specifying any deficiencies in the application. ${ }^{86}$ If Investment Canada does not, within fifteen days after receipt of an application, send either a receipt or notice to the non-Canadian, the application is deemed to be complete as of the date on which Investment Canada received it. ${ }^{87}$

Under subsection 2l(2) the Minister has 45 days after Investment Canada receives a properly completed application to review the proposed or actual investment and notify the applicant as to whether the investment is "likely to be of net benefit to Canada." If a notice is not sent within that 45 day period, the investment is deemed to have been approved. $^{88}$ However, under subsection 22(1), the Minister may extend the review period by 30 days or such longer period as the applicant agrees to if the Minister is unable to complete the consideration of the investment within the initial 45 day period. Again, there is a positive duty on Investment Canada: if the Minister does not notify the applicant of his decision within that further period, the investment is deemed to have been approved. ${ }^{89}$ When the Minister is not satisfied that an investment is likely to be of net benefit to Canada, the Minister must send notice under subsection 23(1) to that effect to the applicant, advising the applicant of its right to make representations and submit undertakings within 30 days from the date of the notice or within such further period as may be agreed on by the applicant and the Minister.

Subsection 23(2) requires that the applicant be given a reasonable opportunity to make representations and submit undertakings to Her Majesty as the applicant sees fit.

As discussed, if the Minister does not approve the investment, it may not be implemented, or if it has been implemented, the applicant must divest itself of control of the Canadian business in question pursuant to subsection 24(1).

Section 25 requires that a non-Canadian that implements an investment in accordance with Part IV must submit such information in its possession relating to the investment as

Ibid. at s.17(2)(b).

lbid. at s. 18(1).

Ibid. at s.18(2).

Ibid. at s.21(2).

lbid. at s.22(3). 
is required from time to time by Investment Canada in order to permit Investment Canada to determine whether the investment is being carried out in accordance with the application filed pursuant to section 17 and any representations made or undertakings given in relation to the investment.

\section{Net Benefit to Canada}

Those investments requiring review and Ministerial approval will be assessed on whether the investment "is likely to be of net benefit to Canada," taking into account the following relevant factors listed in section 20 :

(i) the effect on the level and nature of economic activity in Canada, including employment, resource processing, utilization of parts, components and services produced in Canada and exports from Canada;

(ii) participation by Canadians in the business to be taken over, or in the new business to be established, as well as in the industry of which the business forms a part;

(iii) the effect on productivity, industrial efficiency, technological development, product innovation and product variety;

(iv) the effect on competition within any industry or industries in Canada;

(v) compatibility of the investment with national industrial, economic and cultural policies, which will take into account the cultural and other policies of the provincial governments affected; and

(vi) the effect on Canada's ability to compete in world markets.

To allow the Minister to make his determination under section 21 as to whether he is satisfied that the investment "is likely to be of net benefit to Canada," Investment Canada must refer the following material received by it in the course of its review of an investment pursuant to section 19:

(i) the information contained in the application filed under section 17 and any other information submitted by the applicant;

(ii) any information submitted to Investment Canada by the person or entity from which control of the Canadian business is being or has been acquired;

(iii) any written undertakings to Her Majesty given by the applicant; and

(iv) any representation submitted to Investment Canada by a province that is likely to be significantly effected by the investment. 
In their paper "Regulatory Provisions of the Investment Canada Act with Focus on The Oil and Gas Sector," Francine Matte, Q.C., Corporate Secretary, and Gordon Dewhirst, Vice-President, Review Division, Investment Canada, indicate that in conducting the review process, Investment Canada consults with any province directly affected by the investment. ${ }^{90}$ It also consults with various federal government departments and agencies that are directly involved in the industrial sectors within which a given investment is taking place. This includes consultation with the Bureau of Competition Policy to obtain an assessment on the effect of the investment on competition.

\section{Exceptions to Review Prior to Investment Being Carried Out}

Pursuant to section 16, a non-Canadian shall not implement any reviewable investment before ministerial approval is given; also, the non-Canadian is required to file an application prior to implementation with three exceptions.

Notable to the oil and gas sector are the first two:

If the Minister sends a notice under subsection 16(2)(a) indicating that he is satisfied that a delay in implementing an investment by a non-Canadian would result in undue hardship to the non-Canadian or would jeopardize the Canadian business in question, the application for review may be filed within 30 days after implementation of the investment; and

(ii) Under subsection 16(2)(b), an application for a review of an indirect acquisition of a Canadian business may be filed before or within 30 days after its implementation.

\section{E. MISCELLANEOUS MATTERS}

Part VI of the ICA deals with general matters. Three of them are of significance herein.

\section{Confidentiality}

Generally, information received by Investment Canada and the Minister must be kept confidential. ${ }^{91}$ Subsection 36(3) provides, however, that this restriction does not apply if the person to whom the information relates consents to disclosure and does not apply to disclosures between government officials of the federal government or any province for any purpose relating to the administration or enforcement of the legislation. In addition, subsection 36(4) provides that the following information may be communicated or disclosed:

Gordon Dewhirst, and Francine Matte, "Regulatory Provisions of the Investment Canada Act with Focus on the Oil and Gas Sector" (Address to Legal Education Society of Alberta seminar, 28 February 1990) at 163. 
(i) information for the purposes of legal proceedings relating to the administration and enforcement of the ICA;

(ii) information contained in any written undertaking given to Her Majesty relating to an investment that the Minister is satisfied or is deemed to be satisfied is likely to be of net benefit to Canada;

(iii) information to which the public has access;

(iv) information, the communication or disclosure of which, has been authorized in writing by the Canadian or the non-Canadian to which the information relates;

(v) information contained in any receipt indicating that an investment is not reviewable, notices by the Minister that he is satisfied and investment is likely to be of net benefit to Canada and any demand sent in situations where a Minister believes that a non-Canadian has acted or is acting in contravention of the ICA; and

(vi) other information to which a person is otherwise legally entitled.

However, with respect to information contained in written undertakings, subsection 36(5) provides that, in connection with legal proceedings, no officer or employee of Investment Canada is required to disclose such information where, in the opinion of the Minister or his designate, the communication or disclosure of that information is not necessary for any purpose relating to the administration or enforcement of the ICA and would prejudicially affect the non-Canadian that gave the undertaking in the conduct of its business affairs.

A decision has been made by the Minister not to disclose any undertakings given by non-Canadians except insofar as they have been disclosed in press releases issued by Investment Canada. It would appear that Investment Canada is extremely careful to ensure that confidential information is not made available to unauthorized persons.

\section{Ministerial Opinions, Regulations, Guidelines and Interpretation Notes}

Section 37 of the ICA permits the Minister to provide written opinions regarding the applicability of the legislation to any person. Such opinions are binding upon the Minister and Investment Canada for so long as the material facts on which the opinion is based remain substantially unchanged. To date, 52 opinion summaries have been published by Investment Canada, the last one dated April 30, 1986.

Section 5 of the ICA Regulations mandates the form of notification for notifiable investments, and section 6 mandates the form of application for reviewable investments. Printed forms are available from Investment Canada. 
Section 38 of the Act permits the Minister to issue guidelines and interpretation notes, some of which have been discussed herein, with respect to the application and administration of any provision of the legislation.

\section{Sanctions and Enforcement Proceedings}

Section 39 of the ICA provides that where the Minister believes that a non-Canadian has not complied with the ICA, the Minister may demand compliance. If non-compliance continues, the Minister may apply to a superior court under subsection $40(1)$ for various orders specified in subsection 40(2) enforcing compliance, including:

(i) an order directing a non-Canadian to divest itself of control of a Canadian business on specified terms and conditions;

(ii) an order enjoining a non-Canadian from taking action with respect to an investment which might prejudice the court's ability to grant an effective divestiture order;

(iii) an order directing a non-Canadian to comply with written undertakings given by it in connection with an investment approved by the Minister;

(iv) an order imposing a penalty not exceeding $\$ 10,000$ per day for contravention of the ICA;

(v) an order directing revocation or suspension of voting interests acquired by a non-Canadian for a period specified in the order; and

(vi) an order directing the disposition of voting interests or assets by a non-Canadian.

Failure to comply with an order may result in a finding of contempt of court. In addition, if a non-Canadian outside Canada fails to comply with any such order, section 41 permits a court to vest voting interests or assets in a trustee for the purpose of effecting compliance with the order. If the trustee disposes of the interests or assets, the proceeds are remitted to the non-Canadian after payment of the trustee's fees and costs. ${ }^{92}$

\section{STRUCTURING UPSTREAM INVESTMENTS}

\section{A. INTRODUCTION}

Canada's national policy restricts, in certain respects, the acquisition by non-Canadians of oil and gas businesses. However, this policy has been applied liberally by Investment Canada such that most proposed acquisitions of oil and gas interests are allowed, albeit with certain conditions attached. 
This part of the paper discusses Canada's national policy respecting acquisitions of oil and gas businesses in Canada. Non-reviewable transactions under the ICA and reviewable transactions, approved by Investment Canada as likely to be a net benefit to Canada, are analyzed. Further, a discussion of certain provisions of the ICA is undertaken where such provisions are of interest or concern to the oil and gas sector.

It is noted that Canada's federal energy minister, Jake Epp, is considering a new federal policy to ease the current restrictions on foreign ownership of Canadian oil and gas businesses. He is quoted in the Financial Times of Canada as saying that he hoped to make an announcement on the matter "in the next 45 to 60 days." ${ }^{\text {"3 }}$

In the same article it is inferred that the oil and gas restrictions may be dropped. Alan Bayless wrote:

...he calls the existing law "one of the most stupid policies ever initiated by Ottawa" and generally

proposes "the same conditions for oil and gas as for other industries."

The discussion which follows was prepared prior to Mr. Epp's announcement and reflects the current policy of Investment Canada.

\section{B. NATIONAL POLICY RESPECTING ACQUISITION OF OIL AND GAS BUSINESSES}

The acquisition of control by a non-Canadian of a Canadian oil and gas business, the value of which exceeds $\$ 5$ million, will be subject to review. Such is the case even if the non-Canadian is an American, if the acquired oil and gas business engages in the development or production of oil or natural gas and if the non-Canadian owns an interest in proven reserves of oil or natural gas in Canada.

The $\$ 5$ million threshold value for Americans is limited to "upstream" oil and gas businesses only. If the oil and gas business being acquired does not engage in the development or production of oil or natural gas and does not own an interest in proven reserves of oil or natural gas in Canada, and the investor is an American, then the threshold for review is much higher, currently being $\$ 100$ million and increasing to $\$ 150$ million in 1992. The higher thresholds for Americans could apply to businesses involved in seismic or drilling operations, gathering, processing, transportation, refining, distribution or marketing of petroleum or natural gas products. For example, drilling contracting companies generally are not subject to the $\$ 5$ million threshold because such companies normally do not own an interest in proven reserves of oil or natural gas in Canada.

\section{FOCUS ON OIL AND GAS TRANSACTIONS}

Earlier, it was stated, in part: 
That an investment, which is not exempt, by a non-Canadian to acquire control of a Canadian business, the assets of which are over a prescribed value, is a reviewable transaction requiring a determination by the Minister that such an investment is likely to be of net benefit to Canada.

As was done in Part III of this paper, the underlined concepts will be discussed, but in the context of the oil and gas industry with a focus on the types of transactions which may not be or have been found not to be subject to review or which have been approved by Investment Canada under the ICA.

\section{Exempt Transactions}

Subsection 10(1)(c) of the ICA provides that the Act is not applicable to the acquisition of control of a Canadian business if the acquisition arises in connection with the realization of security granted for a loan or other financial assistance and not for any purpose related to the provisions of the ICA. It has been confirmed by Investment Canada that the realization of security does not need to be by way of foreclosure or other judicial proceedings. The realization may be by way of consensual arrangement in connection with a refinancing.

Investment Canada Opinion No. 19 was issued pursuant to section 37 of the ICA on October 29,1985 . It covered a fact situation in which, pursuant to a refinancing arrangement, a non-Canadian bank was to acquire up to a $67 \%$ interest in a limited partnership to be formed between the bank and a corporation indebted to the bank. The assets of the limited partnership were to consist of assets transferred from the corporation. The Minister was of the opinion that the acquisition constituted an acquisition of control by a non-Canadian, but that the acquisition was in connection with the realization of security granted for a loan or other financial assistance and not for any purpose related to the provisions of the ICA.

This is a broad interpretation of "realization of security given for a loan." A more restrictive interpretation could have limited a realization to the actual taking of legal proceedings by the secured party to enforce its security.

It is noted that the security granted in the first instance must not have been for the purpose of avoiding the provisions of the ICA. Accordingly, only a bona fide refinancing will constitute an exemption pursuant to this subsection.

\section{Non-Canadian}

As discussed earlier, the ICA contains complex rules pertaining to the determination of whether an entity, being a corporation, partnership, trust or joint venture, is Canadian or non-Canadian. Generally, where a majority of the voting interests are owned or controlled in fact by Canadians, the entity is Canadian and vice versa. 
A "voting interest," with respect to a corporation with share capital, means a voting share. ${ }^{44}$ However, with respect to a partnership, trust or joint venture, a voting interest "means an ownership interest in the assets thereof that entitles the owner to receive a share of the profits and to share in the assets on dissolution." ${ }^{15}$ Because the voting interest is tied to the ownership of assets and not necessarily to an entitlement to vote in these types of entities, it might be possible to structure as a joint venture so that non-Canadians have greater rights to the profits of the joint venture, but have no entitlement to share in the proceeds of dissolution or winding up, with the effect that the joint venture is Canadian for the purposes of the ICA.

Conversely, a limited partnership wherein the general partner which controls the limited partnership is a Canadian, but having non-Canadian limited partners with majority ownership of the assets, may be construed as non-Canadian under the ICA because the definition of voting interest focuses on the ownership of the assets of the entity and not the entitlement to vote, as is the case with corporations.

\section{Acquisition of Control}

It will be recalled that under subsection $28(1)$ there are only 3 ways to acquire control of a Canadian business under the ICA, namely:

(i) through the acquisition of voting shares of a corporation incorporated in Canada which carries on a Canadian business or controls, directly or indirectly, another such corporation or other entity that carries on a Canadian business;

(ii) through the acquisition of voting interests in an entity, other than a corporation, that carries on a Canadian business or controls, directly or indirectly, another entity carrying on a Canadian business; or

(iii) through the acquisition of all or substantially all of the assets used in carrying on a Canadian business.

Each method of acquiring control is discussed separately. 
Subsection 28(3)(a) of the ICA provides that the acquisition of a majority of the voting shares (or a majority of the undivided ownership interests therein) of a corporation is deemed to be an acquisition of control. In this regard, an acquisition of $50 \%$ of the voting shares of a corporation is not an acquisition of control - it must be an acquisition of greater than $50 \%$.

However, subsection $28(3)$ (c) goes on to provide that the acquisition of less than a majority, but one third or more of the voting shares of a corporation, is presumed to be an acquisition of control unless it can be established that, upon the acquisition, the corporation is not controlled in fact by the investor through the ownership of voting shares.

It must be remembered that subsection 28(3)(c) only applies to corporations. It does not apply to other entities subject to the ICA, namely, partnerships, trusts or joint ventures.

There have been a number of transactions which have been subject to the application of subsection 28(3)(c). The Minister has issued a number of opinions that if a non-Canadian acquires voting shares in a corporation such that its aggregate shareholding is equal to that of an existing Canadian shareholder, the presumption will be rebutted. For example, if a non-Canadian acquires $50 \%$ of the voting shares of a Canadian corporation carrying on a Canadian business and the remaining $50 \%$ voting shares remain with a Canadian, the subsection 28(3)(c) presumption is rebutted. Investment Canada Opinions No. 9, 18 and 44 deal with this issue. Opinion No. 44, dated March 4, 1986 is the most concise and is reproduced in its entirety:

A non-Canadian-controlled corporation acquired $50 \%$ of the shares of a corporation incorporated in Canada carrying on a Canadian business. The remaining $50 \%$ were owned by a Canadian-controlled corporation. The transaction was not subject to the Act. Although the acquisition of $50 \%$ of the voting shares triggered the presumption of acquisition of control under paragraph $28(3)(\mathrm{c})$, the existence of an equal block of $50 \%$ of the shares demonstrated that control in fact through voting shares had not been acquired and the presumption was set aside.

A similar conclusion, that the presumption of an acquisition of control was rebutted, was reached by the Minister in respect to the acquisition of one third of the voting shares of a corporation by a non-Canadian in Investment Canada Opinion No. 45 issued on April 3,1986 , which provides as follows:

A corporation carrying on a Canadian business was equally owned by two shareholders. The two shareholders each sold shares of the corporation to a non-Canadian investor. Following the transaction, each of the three parties owned one-third of the voting shares of the corporation.

By acquiring one-third of the voting shares of the corporation, the non-Canadian investor was presumed to have acquired control of the corporation by virtue of paragraph 28(3)(c) of the Act. However, the existence of two other equal blocks $(331 / 3 \%)$ of the corporation's voting shares indicated that the 
non-Canadian investor did not control the corporation through the ownership of voting shares. As a result, the non-Canadian was able to rebut the presumption, and the investment was not subject to the Act.

In the foregoing examples, the shareholdings were offset by equal shareholdings with no additional minority shareholdings. However, Investment Canada has taken the approach that where there are minority shareholders of a corporation, one offsetting shareholder will be sufficient to rebut the presumption of an acquisition of control by the non-Canadian if Investment Canada is of the view that the non-Canadian will not influence the votes of the minority shareholders.

An example of this approach occurred in February, 1987 when Investment Canada determined that Husky Oil Ltd. would continue as a Canadian business after a reorganization and acquisition which resulted in $43 \%$ of the voting shares of Husky Oil Ltd. being owned indirectly by Hong Kong businessman $\mathrm{Li} \mathrm{Ka}$-Shing. The determination was made because the seller of the shares, Nova Corp., was to retain $43 \%$ of the voting shares. The remaining $14 \%$ was divided between $\mathrm{Li} \mathrm{Ka}$-Shing's Canadian son with $9 \%$ and Canadian Imperial Bank of Commerce with $5 \% .{ }^{96}$

Notwithstanding concerns that Union Faith Ltd., the direct investor and holding company controlled by Li Ka-Shing, may influence the votes of Li Ka-Shing's son or that they may otherwise act in concert with each other, Investment Canada found that the subsection $28(3)$ (c) presumption had been rebutted for two reasons:

(i) there was an offsetting Canadian shareholder with an equal voting interest to that of Union Faith Ltd; and

it was determined that the votes of $\mathrm{Li} \mathrm{Ka-Shing's} \mathrm{son} \mathrm{in} \mathrm{connection} \mathrm{with} \mathrm{his} 9 \%$ voting interest in Husky Oil Ltd. would not be influenced by his father.

Respecting the non-influence by Li Ka-Shing of his son's votes, on February 28, 1987 , The Globe and Mail reported that Irving Miller, a legislative counsellor with Investment Canada, had said that Investment Canada officials considered the possibility that Union Faith Lid. and Li Ka-Shing could move control of Husky Oil Ltd. outside Canada by influencing the votes of Ka-Shing's son. He is quoted as saying, however: "but we're convinced that this is not the case. Union Faith could not and would not do that." ${ }^{197}$

It is worthy of note that in the absence of any formal arrangement between $\mathrm{Li}$ Ka-Shing, as an indirect controller of Husky Oil Lid., and his son in the nature of a partnership, trust or joint venture, there is no mechanism for deeming that the two combined are a non-Canadian entity such that their acquisition can be considered as one acquisition of $52 \%$ of the voting shares of Husky Oil Ltd., and accordingly, an acquisition of control of Husky under subsection 28(3)(a).

Ronald G. Atkcy, "Investment Canada and the Oil and Gas Sector" (Address to Insight seminar, 18 May 1989) at II.

97. Irving Miller, "Decision to Approve Union Faith's Purchase Of Husky Stake Defended" The Globe and Mail, (28 February 1986) B7. 
The ICA does provide for a "voting group" and Li Ka-Shing and his son could perhaps be considered as such. It is defined in section 3 as follows:

\begin{abstract}
'voting group' means two or more persons who are associated with respect to the exercise of rights attached to voting interests in an entity by contract, business arrangement, personal relationship, common control in fact through the ownership of voting interests, or otherwise, in such a manner that they would ordinarily be expected to act together on a continuing basis with respect to the exercise of those rights.
\end{abstract}

Under this definition it is possible to construe, first through a business arrangement between Union Faith Ltd. and $\mathrm{Li} \mathrm{Ka}$-Shing and then through the personal relationship between $\mathrm{Li} \mathrm{Ka}$-Shing and his son that they are a voting group. However, under the ICA, the concept of a voting group is used in connection with the determination of whether a business is Canadian or not. It is not used in the rules in subsection 28(1) respecting an acquisition of control or the presumptions respecting an acquisition of control in subsection 28(3). In these subsections, reference is made to a non-Canadian only, which by definition is limited to an individual, a government or agency thereof or a corporation, trust, partnership or joint venture.

In Investment Canada Opinion Nos. 1, 8, 11 and 27, the Minister has adopted a narrow interpretation of a "joint venture" and has specifically found that, with respect to the facts presented to it in connection within each of the opinions, that two or more non-Canadians have not acted as a "joint venture" in their acquisition of voting shares of a corporation. For example, in Investment Canada Opinion No. 1 the facts were that two shareholders with non-voting shares of a corporation desired to exercise conversion rights in the shares to exchange them for voting shares. The transaction resulted in the acquisition by each shareholder of $14.35 \%$ of the outstanding voting shares of the corporation. It was opined that:

Since, pursuant to paragraph 28(3)(d), the 'acquisition of less than one-third of the voting shares of a corporation ... is deemed not to be the acquisition of control of that corporation', neither shareholder, taken individually, acquired control of the corporation. Similarly, even if the shareholders were associated so as to form a 'joint venture' as defined by the Act, the combined total of voting shares, $28.7 \%$, also would not constitute acquisition of control pursuant to paragraph $28(3)(d){ }^{98}$

An example in this respect is the acquisition by British Gas PLC of Bow Valley Industries Ltd. British Gas agreed in 1987 to acquire a 33\% interest in the voting shares of Bow Valley. In addition, British Gas agreed to acquire non-voting shares to bring its ownership stake in Bow Valley to $51 \% .^{. \%}$ With a 33\% interest in the voting shares, the transaction was not reviewable because the acquisition is deemed not to be an acquisition of control under subsection 28(3)(d). However, according to an article which appeared in The Globe and Mail on December 22, $1987^{100}$, the agreement essentially allowed British Gas to control Bow Valley with its 33\% equity. At the end of 1987, a British Gas

100. 
officer was to take a seat on Bow Valley's board and the British company was entitled to nominate a majority of Bow Valley directors at Bow Valley's 1988 annual meeting.

British Gas had earlier been denied its bid to acquire $51 \%$ of the voting shares of Bow Valley by Investment Canada because of the federal government's policy of forbidding the acquisition of control of "healthy" Canadian oil and gas companies. This acquisition is summarized in greater detail in the discussion which follows in connection with acquisitions that are likely to be of net benefit to Canada.

\section{Acquisition of Voting Interest}

Subsection 28(3)(b) of the ICA provides that the acquisition of less than a majority of the voting interests of an entity, other than a corporation, is deemed not to be an acquisition of control of that entity. The provisions of subsection $28(3)(c)$, respecting a presumption of an acquisition of control if one third or more of the voting shares of a corporation are acquired is not applicable to entities other than corporations. This position was confirmed in Investment Canada Opinion No. 26 dated November 20, 1985:

A non-Canadian acquired a $35 \%$ interest in an existing joint venture. The transaction was not subject to the Investment Canada Act since under subsection $28(3)$ (b), the acquisition of less than a majority of the voting interests in an unincorporated entity is not an acquisition of control.

\section{Acquisition of All or Substantially All of the Assets of a Business}

Subsection 28(1)(c) of the ICA provides that a non-Canadian acquires control of a Canadian business by the acquisition of all or substantially all of the assets used in carrying on the Canadian business. This naturally leads to the question, what are "substantially all the assets" of a corporation. The Minister has issued two opinions on this issue, in both instances finding that substantially all the assets of a Canadian business were not acquired. The first is Investment Canada Opinion No. 20, dated October 31, 1985:

A Canadian corporation A which was incorporated in Canada carried on a service business in Canada. A Canadian-incorporated corporation, B, a non-Canadian under the Act, carried on a similar business in Canada. A and B formed a new limited partnership in which A held a $40 \%$ ownership interest and acted as limited partner while B owned a $60 \%$ interest and acted as general partner. The limited partnership acquired from $A$ all of the rights in and to customer accounts, purchase orders, service agreements, contracts and other rights to provide services. A retained all of its equipment, vehicles and other assets required to carry on its business. A then entered into a contract with the limited partnership whereby $\mathrm{A}$ managed and discharged all of the obligations arising under the intangible assets acquired by the limited partnership. This transaction did not give rise to an acquisition of control of a Canadian business under the Act. Pursuant of paragraph 28(1)(c) of the Act, an asset purchase results in an acquisition of control of a Canadian business only where "all or substantially all" of the assets used in carrying on that business are acquired. The acquisition of the intangible assets without the equipment and other assets used in the business did not constitute such an acquisition. 
The second opinion, Investment Canada Opinion No. 22, dated November 5, 1985 provides as follows:

A Canadian corporation, A, carried on a business in Canada consisting of a chain of restaurants. A entered into an agreement with B, a non-Canadian corporation, which also carried on a business operating a chain of restaurants in Canada. Under the terms of the agreement, B acquired from A the real estate interests in the various restaurants operated by $\mathrm{A}$ but did not acquire any inventories, any goodwill, any central management assets, any proprietal rights or any other assets identified with the chain operated by A or with its trademarks. It was not B's intention to carry on the business of A but in fact of convert each site into a new and different kind of restaurant to be added to the existing chain operated by $B$. The acquisition of the real estate sites was not an acquisition of control of a Canadian business under the Act. Under subsection $28(1)$ of the Act, control of a Canadian business can only be acquired by asset purchase through the acquisition of "all or substantially all of the assets used in carrying on the Canadian business." The assets acquired in this case did not constitute 'substantially all' of the assets used in operating the restaurant chain.

Further, in Interpretation Note No. 3, a discussion as to what constitutes substantially all the assets of a business is set forth with emphasis placed on "essential assets":

Qualitative Considerations - The determination is not purely a quantitative one based solely on the proportionate value or number of assets to be acquired or retained by the vendor. Assets also have a qualitative value and this value can have a significant effect in the determination of whether the acquisition of less than all the assets of a business constitutes the acquisition of "substantially all" of the assets used in carrying on the business. If an asset essential to the continuance of the business is not acquired, then, notwithstanding the fact that all other assets are acquired, it cannot be said that control of the business is acquired. On the other hand, if the operating assets essential to the continuance of the business are acquired, the test of "substantially all of the assets used in carrying on the Canadian business" would probably be met.

Essential Assets - Assets essential to the continuance of a business are those assets without which the business cannot reasonably be expected to be carried on. Accordingly, if the investor acquires sufficient assets to carry on the former business, and the vendor is left with insufficient assets to be able to continue to carry on that business, the investor can usually be said to have acquired substantially all of the assets used in carrying on that business. In most cases, liquid assets such as cash, promissory notes and investment portfolios are not considered assets essential to the continuance of a business.

The test adopted by the Minister is based upon the judicial interpretation of a sale of substantially all the assets of a corporation in the context of the various business corporation statutes. The Saskatchewan Court of Appeal has written the leading judgment on this topic in Re 85956 Holdings Ltd. and Fayerman Brothers Ltd. ${ }^{101}$ Justice Vancise wrote on behalf of the Court:

If one examines the sale from a purely quantitative perspective, that is, a percentage of the total assets of the company which have been sold, it is obvious that 'substantially all of the assets' have not been 
sold. In my opinion, the issue cannot be determined on a quantitative basis. The purpose of statutes like the one under consideration was to protect the shareholders from a fundamental change in the corporation and to ensure that the means to accomplish the object of the corporation were not impaired. A sale of all of the assets of the company would destroy the corporate business. The phrase "substantially all" is, in my opinion, intended to mean a sale which would effectively destroy the corporate business. There is no Canadian jurisprudence on the interpretation of the meaning of a sale of substantially all the assets of a corporation. There is, however, a reasonably large body of case-law which has been developed in the United States.

The sale will have the effect of destroying the corporation's business because it is a sale of a part of the business so integral as to be essential for the transaction of its ordinary day-to-day business. It follows that the sale is a sale of substantially all the assets. ${ }^{102}$

Hayden and Burns, "Foreign Investment in Canada: A Guide to the Law" set forth a useful list of factors to be considered when making a determination as to whether substantially all the assets of a business are being acquired: ${ }^{103}$

1. Is the physical location of the business operation the same as those of the other divisions of the corporation?

2. Is the equipment of the business operation used or usable in connection with any of the other divisions?

3. Is inventory acquired separately for the business operation, is it stored in a particular portion of the premises allotted to the operation, and is it accounted for separately?

4. Are the sources of material for the business operation different from those for the other divisions?

5. Are the customers for the products of the business operation different from those for the other divisions?

6. Are the staffs who carry out the different operations separate and distinct from each other?

7. Are the general accounting procedures broken down as between business operations? For example, to what extent are expenses incurred separately for and charged to the separate operations? Does each division have its own profit and loss statement?

8. Are the operations under the control of different members of the board of directors? 
9. Is there a single union or employee contract for the whole corporation? and

10. Is there a single insurance and pension plan covering all employees of all operations of the corporation?

From an oil and gas perspective, there are two problems which a non-Canadian may unexpectedly encounter when making an acquisition of assets. First, the non-Canadian may desire to acquire less than a majority of the voting interest in a joint venture by acquiring the interest in the joint venture of one of the joint venturers. If that joint venturer is a Canadian business under the ICA and the working interest comprises all or substantially all the assets of the joint venturer the transaction will be reviewable - not as a result of the acquisition of less than a majority voting interest in the joint venture, but on the basis of an acquisition of all or substantially all of the assets of a Canadian business.

In the oil and gas context, a problem could arise in situations where a non-Canadian desires to acquire less than majority working interest in an operated oil and gas property from a Canadian who's only asset is that working interest. While the working interest is a part of a joint venture and the non-Canadian may be acquiring less than a majority voting interest in the joint venture, the transaction could be reviewable because the working interest comprises all the assets of the entity selling it. This makes the acquisition of working interest from small Canadian oil and gas businesses more difficult than from the larger ones.

This problem has been recognized by Investment Canada and in its latest guidelines, Acquisitions of Oil and Gas Interests; it is hinted that the acquisition may, depending on the facts involved, be viewed as an acquisition of a minority voting interest in a joint venture and not an acquisition of "all or substantially all the assets" of a business. The guidelines provide:

However, if the minority interests being acquired represent all or substantially all of the oil and gas business of the vendor, there will be an acquisition of control of the vendor's business. Interpretation Note No. 3 assists investors in determining if there is an acquisition of 'all or substantially all of the assets' of a business.

The acquisition of minority working interests may also be subject to the Act where there is an acquisition of a controlling interest in a corporation which holds the minority working interests. Depending on the facts however, it may be possible to view such an acquisition as in essence the acquisition of minority voting interests in a joint venture or ventures (rather than as the acquisition of shares in a corporation), in which case the transaction would not be subject to the Act. ${ }^{104}$

The second problem which a non-Canadian may encounter arises in connection with subsection 31(2) of the ICA which implicitly contemplates that a part of a business that is capable of being carried on as a separate business is a separate business. In 
Interpretation Note No. 2 this interpretation of subsection 31(2) is expressly made by Investment Canada. It reads, in part:

Definition of Canadian Business - The meaning given to a Canadian business by section 3 of the Act is extended by subsection $31(2)$ to include 'a part of a business that is capable of being carried on as a separate business'. This Note identifies factors which are taken into account in determining whether the acquisition of assets constitutes the acquisition of a separate business within subsection 31(2)."

Concept of "Separate Business" - The concept of a separate or separable business necessarily implies the existence, prior to the acquisition, of an identifiable part of an existing Canadian business having the capacity to be carried on as a separate business. This will depend upon the circumstances of each case, particularly as they bear on the degree of actual or necessary interconnection or interdependence between the part and the remainder of the vendor's business operations."

Relevant Factors - The following factors may be relevant to this determination.

(a) Does the part have separate accounting mechanisms, management, advertising, selling, purchasing, delivery, customers, or an identifiable group of employees?

(b) Are the operations of the part carried on under a separate licence, patent, or similar right?

(c) Is the part carried on in separate premises, or are the physical assets of the part segregated from the other business operations of the vendor?

(d) Does the part supply or provide some service which is more than purely incidental or ancillary to the main business operations of the vendor?

Acquisition of Assets of Part - When a separable part of a business has been identified, it must then be determined whether the purchaser is acquiring all or substantially all of the assets of the identifiable part. $^{\text {IOS }}$

In circumstances where a non-Canadian is acquiring a division of or an identifiable part of the business of a Canadian business, such as all of the oil and gas interests in an area, consideration should be given to subsection 31(2) because if the assets acquired are separable and can be considered a separate business, the transaction could become reviewable if all or substantially all of the assets of the separate business are acquired.

Matte and Dewhirst, in their previously cited article, infer that each working interest may be considered separate businesses in certain circumstances. They wrote:

Interpretation Note No. 2 identifies factors which are taken into account in determining whether the acquisition of assets constitutes the acquisition of a separate business within the meaning of subsection 31(2) of the Act. The concept of a separate business necessarily implies the existence, prior to the acquisition, of an identifiable part of an existing Canadian business having the capacity to be carried on 
as a separate business. With respect to oil and gas transactions, the questions that may be relevant to a determination as to the degree of actual or necessary interconnection or interdependence between the two business operations might be as follows:
(a) different participants in each property
(b) different levels of participation
(c) different operators
(d) separate operator records
(e) each business being acquired is subject to a different agreement. ${ }^{106}$

\section{Business}

Section 3 of the ICA defines "business" as any undertaking or enterprise capable of generating revenue and carried on in anticipation of profit. With respect to what constitutes a business, Investment Canada has made some pronouncements of significance to the oil and gas industry. These pronouncements can be divided into the three components of the definition and will be discussed as follows:

(a) carried on in anticipation of profit;

(b) capable of generating revenue; and

(c) undertaking or enterprise.

(a) Carried On In Anticipation of Profit

In Interpretation Note No. 4, the Minister has confirmed that a profit-making motive is essential to the classification of an enterprise or undertaking as a business. However, the motive can be for future profits. The Minister wrote: ${ }^{107}$

If an undertaking or enterprise is carried on with a charitable or other non-profit objective, it will not be considered to be a business. Profit-making must be a purpose of the undertaking or enterprise; however, even if it is being carried on at a loss in the expectation of future profit, it is considered to be a business.

Permanent ceasing of operations, or in connection with oil and gas wells, abandonment, will be sufficient for a finding of a lack of a profit-making motive. In Interpretation Note No. 1, the Minister confirmed that a "defunct" business is not a business for the purposes of the ICA: 
Defunct Business - A business which has ceased normal operations and become defunct, as exemplified when the business has permanently closed due to its unprofitability, or has been permanently abandoned or discontinued due to a number of reasons, including depletion of reserves, obsolete plant, machinery, equipment, technological processes or product lines, and the closure did not occur for any purpose related to the Act, is not a 'business' as defined in section 3 of the Act, and hence the acquisition of its control would not be subject to the Act. Of course, this determination is a question of fact to be determined by the circumstances of each case.

Temporary Closures - A business which has temporarily closed or suspended its operations for any number of reasons including labour disputes, shortages of raw materials, shortage in demand for its product, periodic fluctuations in the business cycle or temporary financial difficulties is still considered to be a "business" as defined in the Act.

In an opinion issued July 29, 1985, the shutting-in of a well because it was not "economically viable" was a factor in a determination that three oil and gas leases did not constitute a business. There are few facts set out in the opinion summary, so a determination of its scope is not possible. However, it is noteworthy that the well was shut-in and not abandoned. Investment Canada Opinion No. 4 reads as follows:

The only assets of an entity, the control of which was acquired, consisted of three oil and gas leases. Only one well had been drilled on these properties and it had been shut in since it was not economically viable. It was determined that the entity was not carrying on a business since the definition of a "business" in Section 3 of the Act requires that a "business" be "capable of generating revenuc." Interpretation Note No. 4 on the meaning of "business" notes further that, with respect to oil and gas properties, this definition of "business" means that exploratory properties, as opposed to producing properties, do not constitute a business.

Finally, it would appear also that a non-Canadian may acquire free from application of the ICA, the assets of a business through its liquidation if two tests are met. In Interpretation Note No. 1, the Minister has discussed the policy of Investment Canada respecting the insolvent business which has been placed in the hands of a trustee in bankruptcy or a receiver and the tests which must be met in order to not classify the insolvent business as a business for the purposes of the ICA:

Receivership or Bankruptcy - A business has not gone defunct by reason only that its assets have been placed in the hands of a Trustec in Bankruptcy pursuant to the Bankruptcy Act, or that its assets have been placed in receivership. Provided the Trustee or Receiver is carrying on the operations with a view to disposing of the business as a going concern, or to reorganizing its affairs, it is still considered a "business." However, where circumstances have degenerated to the extent that the business is incapable of being carried on or of being sold as a going concern, and the Trustee or Receiver takes steps to liquidate the assets on a piecemeal basis, it is no longer considered to be a "business" as defined in the Act.

Interpretation Note No. 1 makes it clear that for the purposes of the ICA a business does not exist, if after appointment of a trustee or receiver, the business is incapable of being carried on or of being sold as a going concern. If these tests are met, it should not matter that a non-Canadian acquires all the assets sold by the trustee or receiver because 
there is no "business" to trigger the provisions of subsection $28(1)$ (c) relating to the acquisition of all or substantially all the assets of a Canadian business.

\section{Capable of Generating Revenue}

In the eyes of Investment Canada, steps, in the nature of drilling a well, to recover proven reserves contained within oil and gas properties must be taken before the property will be considered a business. Interpretation Note No. 4 reads in part:

\footnotetext{
Oil and Gas Properties - A property upon which only exploration for oil or gas has been conducted is not considered to be a business. A property which contains oil or gas reserves is considered to be a business if production of oil or gas is actually occurring or if it has been determined that the property contains economically recoverable quantities of oil or gas and the drilling of a well to recover such oil or gas for the purpose of production has been commenced. A property containing recoverable reserves which is capable of production but which has been temporarily shut-in is considered to be a business.
}

The Minister has clarified, by issuance of this interpretation note, that the drilling of an exploratory well, prior to the determination that the oil and gas property contains recoverable quantities of oil or gas, will not constitute the property as a business under the ICA. However, if the well is ultimately put into production, the property will be reclassified as a business. Where a determination that a property contains recoverable quantities of oil or gas, the interpretation note would suggest that the critical time for classification of it under the ICA will be the commencement of drilling of a well.

\section{Undertaking or Enterprise}

The Minister has recently issued a new set of guidelines respecting acquisitions of oil and gas interests. The guidelines deal with acquisition of royalty and net profit interests and working interests.

Distinguishing a royalty or net profit interest from a working interest can, depending on the circumstances, be difficult. However, generally, a royalty or net profit interest does not connote an ownership interest in the oil and gas property in that the holder of the interest does not participate in decision-making, is not liable for losses which accrue to the property and will not be entitled to share in the liquidation of the assets of the property.

Regarding royalty and net profit interests, Investment Canada considers them to be neither voting interests nor assets used in carrying on a Canadian business. Accordingly, the acquisition of such an interest will not ordinarily be treated as the acquisition of control of a business.

The recent guidelines have set out detailed principles in the determination of what constitutes a business in connection with working interests in oil and gas properties. The guidelines provide a useful insight to Investment Canada's policies and are reproduced, in part, herein: 


\begin{abstract}
"Business - The acquisition of a working interest in a property on which only exploration activities are conducted is not treated as the acquisition of an interest in a "business," and is not subject to either notification or review. The acquisition of a working interest in a property which contains recoverable reserves will usually be treated as the acquisition of an interest in a "business," and may be subject to either notification or review, depending on the size of the interest being acquired and the asset size of the business. Interpretation Note No. 4 provides further guidance as to when an oil and gas property is considered a "business."
\end{abstract}

Acquisition of Control - Under section 28 of the Act, control of a business may be acquired through the acquisition of either voting interests or assets.

With respect to oil and gas properties, the relationship among the participants in a particular field or well will ordinarily constitute a joint venture, as defined under section 3 of the Act. A voting interest, with respect to a joint venture, is defined under section 3 of the Act as "an ownership interest in the assets thereof that entitles the owner to receive a share of the profits and to share in the assets on dissolution." The acquisition of a working interest is thus equivalent to the acquisition of a voting interest in a joint venturc. The acquisition of less than a majority ( $50 \%$ or less) of the voting interests of a joint venture is deemed not to be an acquisition of control under paragraph $28(3)$ (b) of the Act. Therefore, if the interest being acquired, combined with any existing interest owned by the investor in the property, does not exceed $50 \%$, there is no acquisition of control and the transaction is not subject to the Act....

Non-Unitized Properties - Each property or well governed by a separate operating agreement is treated as a separate business. Therefore, if the investor is acquiring a package of interests in separate properties, and there is no acquisition of a majority working interest in at least one of those properties, there will be no acquisition of control of any business, notwithstanding the value of the investment.

Unitized Properties - Each set of properties subject to a unitization or pooling agreement is treated as one Canadian business. Therefore, where an investor is acquiring working interests in one or more properties that are the subject of a unitization or pooling agreement, he may acquire a majority interest in that or those properties without being subject to the Act, so long as his overall holdings will not constitute a majority of the interests in the unit or pool. ${ }^{10 x}$

A transaction that caught the attention of those involved in the oil and gas industry was the reported acquisition by Amerada Hess Corp. of a majority of the oil and gas assets of Placer Cego Petroleum Holdings Ltd.

Because each of Placer Cego's working interests in oil and gas properties were considered to be individual businesses in the nature of joint ventures, Amerada was able to acquire the minority working interest of Placer Cego in various oil and gas properties. Where Placer Cego owned a majority working interest in a property, Amerada acquired Placer Cego's working interest up to 50\% of the total working interest in the property and Poco Petroleum Limited purchased that portion of the working interest exceeding $50 \%$. 


\section{An article in the Financial Times of Canada, February 4, 1991, discussed the Placer Cego case:}

A little-noticed decision by Investment Canada has substantially gutted federal restrictions on foreign take-overs of Canadian-owned oil and gas companies. Such restrictions have been a cornerstone of federal energy policy since the mid-1970s. They were intended to keep the country's natural resources in Canadian hands for reasons of national security as well as national pride....

But Investment Canada quietly changed direction last September, when it allowed Placer Dome Lid., one of Canada's biggest mining companies, to sell $80 \%$ of its thriving Calgary-based oil and gas unit, Placer Cego Petroleum Holdings Lid., to New York-based Amerada Hess Corp. of New York. Amerada paid some \$260 million for the Placer Cego holdings. Poco Petroleums Lid. of Calgary, controlled by Vancouver gold-miner Corona Corp., bought the remainder of Placer Cego’s assets for about \$29 million at the same time.

The most recent official description of federal policy came in a 1988 letter from Finance Minister Michael Wilson to U.S. Secretary of State James Baker. Referring to foreign takeovers in the oil and gas sector, Wilson said in part that "Investment Canada will disallow the direct acquisition of a healthy Canadian-controlled business with assets of at least $\$ 5$ million."

Charles Byron, Investment Canada's director of investment review for the resources and manufacturing sector, declined to discuss details of the Amerada Hess transaction, citing commercial confidentiality. But Byron said the official policy, looser than is commonly understood, is that the agency won't intervene in the sale by a Canadian-owned company to a non-Canadian of up to $50 \%$ of any single oil well or property.

Byron said the federal agency therefore simply decided that the Placer Cego sale didn't fall under its purview. The distinction is important because Amerada didn't buy control of any individual Placer Cego joint venture. Where Placer Cego held a majority interest in a well or a group of wells, Canadian-owned Poco purchased a portion of that interest to ensure Amerada's stake was $50 \%$ or less. Poco was also brought in to ensure that Amerada Hess didn't end up with 'all or substantially all' of the acquired company as defined under Investment Canada's rules, sources say. Nevertheless, Hess wound up with $80 \%$ of the assets."...

Now, the Placer Cego sale shows how to sidestep those rules. Rather than considering Placer Cego as a single commercial enterprise. Investment Canada decided that each Placer Cego joint-venture oil or gas property could be considered a business of its own. Placer Cego actively invested in joint ventures to reduce its exposure to individual exploratory failures.

Since many Canadian-owned oil and gas companies participate heavily in joint ventures, the rule is sure to have broad applicability and could dramatically increase the sale of Canadian oil and gas reserves to non-Canadians. That would be good news in the oil patch, where Canadian-owned companies and assets worth billions are up for sale, with hardly any Canadian buyers. In fact, Byron concedes that a 100\% 
Canadian-owned joint venture could be sold in stages to two or more foreigners, as long as no purchaser ended up with more than $50 \% .^{10 \%}$

\section{Value}

A transaction in which direct control of an entity is acquired by a non-Canadian is reviewable if the value of all the assets of the entity, and not just the proportionate value of the assets of the entity acquired, is $\$ 5$ million or more for non-Americans ${ }^{100}$ and $\$ 100$ million or more (moving to $\$ 150$ million or more in 1992) for Americans ${ }^{111}$. Where the non-Canadian acquires all or substantially all the assets of an entity, the applicable value is the value of the assets acquired.

Where indirect control of an entity is acquired, the threshold value is $\$ 50$ million for non-Americans ${ }^{112}$ and $\$ 500$ million (unlimited in 1992) for Americans. ${ }^{113}$ The threshold value is determined by calculating the aggregate value of the assets of the entity carrying on the Canadian business, and of all other entities in Canada, the control of which is acquired.

It must be remembered that these higher threshold limits do not apply to Americans where the business being acquired engages in the development or production of oil or natural gas and owns an interest in proven reserves of oil or natural gas in Canada.

Under the ICA Regulations, the value is determined on the basis of the audited financial statements for the fiscal year immediately preceding the implementing the investment. ${ }^{114}$ Accordingly, the value is the book value. Investment Canada has adopted special policies for the determination of the value of joint ventures in which working interests in oil and gas properties are acquired. In Investment Canada Opinion No. 32 dated December 27, 1985, a determination was made on the basis of the cost as listed by the operator of the oil and gas properties:

The investor was acquiring an undivided majority interest in a shut-in gas well and in the petroleum and natural gas rights underlying certain properties adjacent to the well. The shut-in gas well and adjoining lands contained economically recoverable quantities of gas that were capable of production and, as a result, constituted a Canadian business.

The investor acquired its undivided majority interest by purchasing three undivided minority interests from three separate vendors. None of the vendors attributed a separate value to their interest in the well and lands in their audited financial statements. The vendors' audited financial statements could not be used, therefore, to ascertain the value of the well and lands. As a result, the value of the well and lands was determined from the value attributed to them by the operator.

Financial Times of Canada (4 February 1991) 1.

Supra, note 1 at s.14(3).

Ibid. at s.14.1(2).

Ibid. at s. 14(4).

Ibid. at s.14(6).

Supra, note 75 , at s.3. 
The operator listed the oil and gas assets it managed at cost. Since the cost of the lands together with the total costs of drilling the well and acquiring and installing the wellhead, tubing, casing and associated equipment, etc., was less than $\$ 5$ million, the investment to acquire an undivided majority interest in the well and lands was subject to notification only.

The method of determination of value set forth in the recent guidelines issued by the Minister take a similar approach. The guidelines assume that financial statements are not prepared for joint ventures and provide that the book value of an interest, as shown in the vendor's financial statements, may be extrapolated to determine the value of the entire joint ventu:e:

Calculation of Assets - If an investor determines that he is acquiring control of one or more oil and gas businesses, he must then determine which filing procedure applies under the Act - notification or application for review. This depends not simply on the value of the interest being acquired but on the overall asset value of the property or properties of which control is being acquired.

Under subsection 14(3) of the Act, the threshold for review for a direct acquisition of control of a Canadian business is $\$ 5$ million. Subsection $3(1)$ of the Investment Canada Regulations (the "Regulations") states that, where control of an entity is acquired, the value of the assets shall be the value of all assets of the entity, as shown on the audited financial statements of the entity for its most recent fiscal year i.e. book value. With respect to the acquisition of a controlling interest in an oil and gas property or unit, the "entity" is the "joint venture" between the participants on the property or unit. Financial statements are not ordinarily prepared in relation to the activities of the "joint venture." Therefore, to determine the asset value of the joint venture, it is necessary to aggregate the value of the individual interests in the joint venture.

Where the investor encounters problems in aggregating the individual interests, the Act permits the investor to complete his notification or application for review by giving reasons for his inability to provide any required information (see subsections 13(1) and 18(1)). Assuming that Investment Canada is satisfied that the investor cannot provide an aggregated value of all interests in the joint venture, the best available approximation of the asset value of the joint venture will usually be accepted. For example, if the vendor of an interest is able to provide the purchaser with a book value for that interest, determined in accordance with generally accepted accounting principles (GAAP), then the purchaser will usually be permitted to extrapolate from that figure an approximate value for the entire joint venture. ${ }^{115}$

The vendor's book value is not necessarily the best determinant as it can be a reflection of one of a number of values. For example, it could reflect the proportionate working interest cost of acquiring and putting the property or properties into production, less depreciation and depletion. However, where the vendor acquired its working interest from a third party, its book value will reflect the purchase price paid to the third party, presumably the fair market value at that time, less depreciation and depletion. Further, the net book value may incorporate costs related to other properties of the vendor, thereby increasing the book value of the properties to be sold, if the vendor has adopted the full cost method of accounting as opposed to the successful efforts method. In any event, the 
book value of the property or properties covered by the working interest will likely, in most circumstances, be less than an amount extrapolated from the purchase price paid by the non-Canadian to the vendor.

Finally, where control of more than one entity is acquired in the same transaction, the value will be calculated as the aggregate value of all entities acquired in making a determination as to whether the acquisition is reviewable. This Investment Canada policy is also set forth in the recent guidelines:

Where control of more than one entity is acquired as part of the same investment, the investor must aggregate the value of all assets of all entities of which control is acquired, to detcrmine if the investment is reviewable (see paragraph $14(3)$ (b) of the Act and subsection 3(2) of the Regulations). Therefore, if a number of controlling interests in different oil and gas businesses are being acquired as part of the same transaction, the investor must aggregate the values of the joint ventures in respect of all those businesses to determine which filing procedure, notification or application for review, applies. ${ }^{116}$

\section{Likely to be a Net Benefit to Canada}

$$
\text { Acquisitions Approved After Review }
$$

It will be recalled that the ICA prescribes several factors to be taken into account by the Minister when making a determination as to whether an investment is likely to be of net benefit to Canada. The factors, set forth in section 20 , can be summarized as follows:

(i) the effect of the investment on employment, resource processing and on the utilization of parts, components and services produced in Canada;

(ii) the degree and significance of participation by Canadians in the new Canadian business being invested in;

(iii) the effect of investment on productivity, industrial efficiency, technological development, product innovation and product variety in Canada;

(iv) the effect of the investment on competition in Canada;

(v) the compatibility of the investment with national industrial, economic and cultural policies, taking into account industrial, economic or cultural policies of the federal or any provincial governments; and

(vi) the contribution of the investment to Canada's ability to compete in world markets.

In connection with the oil and gas industry, subheading (v) is important. As a result of long standing policies of protectionism in the oil and gas sector, the national policy 
respecting Canadian ownership of the oil and gas industry has resulted in greater restrictions on the ability of non-Canadians to acquire Canadian-controlled oil and gas businesses.

As discussed, the exchange of letters between the Honourable Michael H. Wilson and the Honourable James A. Baker III on May 12, 1988 sets forth a statement of the current oil and gas policy formulated by the Department of Energy, Mines and Resources (Canada). ${ }^{17}$ In a nutshell, the policy is as follows:

(i) the direct acquisition of a healthy Canadian-controlled oil and gas business with assets in excess of $\$ 5$ million will be disallowed;

where a Canadian-controlled business is in clear financial difficulty, the Minister will review the proposed acquisition to evaluate its net benefit to Canada and may negotiate undertakings by the investor in relation to the review criteria; and

the Minister will normally allow the direct acquisition of a foreign-controlled business with assets of at least $\$ 5$ million, and the indirect acquisition of a foreign-controlled business with assets of at least $\$ 50$ million, subject to agreement on conditions related to Canadian ownership and investment spending.

This policy sets forth the general principles which will be followed by Investment Canada in its determination as to whether an acquisition is likely to be of net benefit to Canada. Each of the aforementioned headings will be addressed individually in a review of investments approved by Investment Canada.

$$
\text { Healthy Canadian-Controlled Business }
$$

Perhaps the best example of Investment Canada refusing to allow the acquisition of control of a Canadian-controlled oil and gas company relates to the British Gas PLC acquisition of $33 \%$ of the voting shares of Bow Valley Industries Ltd. The acquisition of a $51 \%$ voting interest had earlier been rejected by Investment Canada. ${ }^{118}$ The Globe and Mail summarized the transaction in a report dated December 22, 1987:

In a restructured deal that neatly sidesteps federal rules, British Gas PLC has announced that it has a binding agreement to spend $\$ 837$ million to take over Bow Valley Industries Ltd.

Investment Canada rejected an earlier British Gas bid to take 51 per cent control of Bow Valley, one of Canada's largest oil and gas exploration companies. Federal rules prohibit a forcign company from buying more than 33 per cent of a healthy Canadian energy company. (Bow Valley had a profit of \$31.2-million in the first nine months of 1987.)

Efforts to persuade federal Energy Minister Marcel Masse to relax the rules proved unsuccessful. 
However, the revised deal - which is not reviewable by Investment Canada - essentially allows the mammoth British utility to control Bow Valley with 33 per cent of the voting equity....

Under the proposal, British Gas, which already owns about two million Bow Valley shares, would spend $\$ 320$ million to buy an additional 16 million common shares from existing shareholders at $\$ 20$ a share.

A further $\$ 517$ million would be invested in so-called preferred shares: newly issued non-voling securities convertible into voting stock of Bow Valley. The price of the shares purchased from the company would be equivalent to $\$ 18$ a common share.

The deal would increase the British Gas stake in Bow Valley to 51 per cent of total equity, but ownership of voting stock would remain at 33 per cent to satisfy the Canadian regulatory authorities.

The proposal is conditional on British Gas getting 51 per cent of Bow Valley's equity, as well as approval by regulatory authorities and Bow Valley shareholders."

If and when British Gas PLC exercises its rights in connection with the conversion of the non-voting preferred shares, the transaction will be reviewable.

\section{Canadian-controlled Business in Clear Financial Difficulty}

Often cited as the best example of an acquisition by a non-Canadian of a Canadian business in financial difficulty which was allowed by Investment Canada is the Dome Petroleum Ltd. merger with Amoco Canada Petroleum Co. Lid. putting control of the merged company in the hands of Amoco Corp. ${ }^{120}$ In approving the transaction, Investment Canada extracted a number of undertakings from Amoco. The undertakings are summarized in an article which appeared in the Globe and Mail on December 22, 1987:

Investment Canada has approved a proposed \$5.5-billion deal that would put the largest petroleum producing company in Canada in the hands of Amoco Corp. of Chicago.

After eight months of research, examining the issue of Canadian ownership of the oil industry and a proposed Canadian share issue in the new company, the federal agency yesterday gave the green light to the proposed merger of Amoco Canada Petroleum Co. Ltd. and debt-ridden Dome Petroleum Lid., both of Calgary. Last week, the time period for U.S. objections to the takeover expired with no formal complaints about the proposed deal.

The approval carries several conditions, including the provision that Amoco offer at least 20 per cent of the shares in the merged company to Canadians over 15 years. The merged company is also committed to invest $\$ 2.5-$ billion in the Canadian oil patch over the next five years and pay no dividends or interest to Amoco Corp. over that time.

\footnotetext{
114. Supra, note 100 at B1.

120. Supra, note 96 at 5.
} 
Amoco also will have to sell Dome's interest in Placer Dome Inc. and its interest in a Northern Ontario gold mine. As well, the company will have to sell properties having a total of 10,000 barrels a day of oil or equivalent to Canadian companies as part of the transaction. The deal must still go before shareholders, creditors and the Alberta Court of Queen's Bench for final approval.

Amoco also promised that the new company would keep substantially all Dome employees, and ensure that at least nine of its 12 directors and 70 per cent of the management team are Canadians. Amoco also promised to pay the $\$ 150$-million Dome owes the federal Government in unpaid Petroleum Gas Revenue Tax.

Before the deal was reviewed, Amoco had offered to make the \$2.5-billion oil patch investment and take no dividends as well as paying the \$150-million in PGRT. But the possibility of selling shares in the new company was only raised by Amoco Canada president $T$. Donald Stacy before a Senate committee last spring after Opposition politicians had objected to the deal.

Mr. Stacy said in an interview yesterday that the federal Government had made "a tough deal, but they aren't asking us to do anything we think is unreasonable." 121

Dome Petroleum Ltd. was without a doubt a company which was "in clear financial difficulty."

In another transaction, Bow Valley Industries Ltd. was permitted to take over the oil and gas properties in southern Saskatchewan held by Bonanza Oil and Gas Ltd. On March 8, 1989, The Globe and Mail reported that according to Gordon Dewhirst, Vice-President of Investment Canada, the sale was allowed because Bonanza was in difficult financial circumstances. ${ }^{122}$ No reasons were cited for this determination.

Finally, recent approval was given by Investment Canada for a group led by Hong Kong businessman Li Ka-Shing to acquire Nova Corp.'s remaining 43\% share of Husky Oil Ltd. Michael Wilson, minister responsible for Investment Canada, was reported in the Globe and Mail to have said that Husky was experiencing financial difficulty and therefore the takeover was allowed. ${ }^{123}$

What remains unclear is what Investment Canada considers to be a healthy company and, conversely, what it considers to be a company in clear financial difficulty. To date Investment Canada has not issued any pronouncements as to what is meant by these terms, leaving it up to potential investors to devise some creative suggestions. 
(iii) Acquisitions of Foreign-Controlled Businesses

The acquisition of Texaco Canada Inc. by Imperial Oil Ltd. in 1989 is an example of an acquisition of a foreign-controlled business. ${ }^{124}$ The Globe and Mail reported on February 25, 1989'25 and April 20, 1989 acquisition on the basis of an undertaking by Imperial Oil Ltd. to make $\$ 700$ million per year in expenditures in its upstream operations, to offer to sell $\$ 550$ million of oil and gas assets to Canadian companies over five years and to offer jobs to all of Texaco Canada Inc.'s employees. The Globe and Mail reported that the combined upstream expenditures by Imperial Oil Ltd. and Texaco Canada Inc. were $\$ 660$ million in $1987 . .^{127}$ It is noted that the federal Competition Bureau required further undertakings of Imperial Oil Lid. in connection with downstream operations.

\section{(b) Determination of Net Benefit to Canada}

In recent guidelines issued by the Minister related to the administrative procedures of Investment Canada, an outline was provided of how a determination is made as to whether an investment is likely to be of a net benefit to Canada. It would appear that the benefits to Canada need only outweigh the negative effects, and if such is the case, the investment will be approved:

Net Benefit - In reaching a decision, judgments will be made both in measuring the effects of a proposal in relation to the relevant individual factors of assessment and in measuring the aggregate, net effect after offsetting the negative effects, if any, against the positive ones. An investment will be determined to be of net benefit when the aggregate net effect is positive, regardless of its extent. ${ }^{12 x}$

There are no guidelines or interpretation notes indicating how Investment Canada quantifies the net benefits and negative effects to Canada.

\section{(c) Review Policy}

In his Administrative Procedures Guidelines, the Minister has set forth certain procedures that will be followed in the administration of the review and monitoring provisions of the ICA.

Specifically, investors are encouraged to contact officials at Investment Canada at the earliest stages of the development of their investment projects and prior to the filing of applications. These consultations are encouraged so as to provide a useful forum for

Christopher Waddell, "Investment Canada Approves Imperial Bid for Texaco Canada" The Globe and Mail (25 February 1989) BI.

126. Leonard Zehr, "Imperial Oil to Sell \$1 Billion in Assets." The Globe and Mail (20 April 1989) B1.

127. Ibid.

12x. ICA, Guidelines - Administrative Procedures. 
discussion and the exchange of views which may serve to eliminate possible difficulties and encourage the development of investments of benefit to Canada. ${ }^{129}$

Further, investors are encouraged to put as much detail and precision into their plans for the Canadian business as is possible thereby reducing the likelihood that undertakings will be necessary to supplement the plans. It is made clear, however, that in certain cases, specific undertakings may be required to provide greater assurances when issues critical to the determination of the net benefit to Canada arise. ${ }^{130}$

It is a policy of Investment Canada that while other federal government departments and provincial governments are regularly consulted in the review process, representations are not solicited from any other persons. However, where unsolicited representations are received that could have an adverse bearing on the determination of the net benefit of the investment, the applicants are advised of the substance of those representations and will be given an opportunity to respond to them. Finally, the Minister may use any facts revealed by an alternative buyer which are relevant to provide an additional perspective in the assessment of the applicant's investment. ${ }^{131}$

In the monitoring of investments, an evaluation of performance will ordinarily be made eighteen months after the implementation of the investment. If the evaluation discloses implementation substantially consistent with the original expectations and subsequent economic circumstances, and there are no major commitments yet to be complied with no further monitoring will ordinarily take place. However, if the evaluation discloses otherwise, the government and the investor will together determine an appropriate time for future follow-up. It is a policy of Investment Canada that where an inability to fulfil a commitment is clearly the result of factors beyond the control of the foreign investor, the foreign investor will not be held accountable. ${ }^{132}$

\section{CONCLUSION}

Canada's deep-rooted foreign ownership policies have undergone significant changes, especially in the oil and gas industry. After a period in the 1970s where Canada's relationship with foreign investors could at best be described as strained, the 1980s have seen a turnaround, making Canada a much more positive place for foreign investment.

This approach is borne out by Investment Canada. The general perception among those dealing with the Agency is that its mandate is to promote investment in Canada and its dealings are in keeping with this mandate. While there are continuing restrictions in the oil and gas sector, the ICA is interpreted and applied in a manner which is conducive to such investment.

ICA, Guidelines, ihid. Pre-filing Meetings.

ICA Guidelines, ibid. Third Party Representations.

ICA Guidelines, ibid. Monitoring of Investments. 